\title{
ALGUNS ASPECTOS DA VIDA QUOTIDIANA NUM COLÉGIO FEMININO NO SÉCULO XIX: O CASO DO REAL COLÉGIO URSULINO DAS CHAGAS DE COIMBRA (1874-1880)
}

\author{
Irene Maria Vaquinhas*
}

\section{INTRODUÇÃO}

Num domingo de Setembro de 1850 , pelas 17 horas, deu entrada no Real Colégio Ursulino das Chagas de Coimbra, ao tempo sediado no convento de Santa Ana, a "Sra. D. Luísa Augusta da Rocha", como referia o jornal $O$ Observador, de sete anos de idade, sobrinha do lente da Faculdade de Direito, Manuel António Coelho da Rocha, recentemente falecido'. Acompanhavam-na um numeroso séquito composto pelo Conselheiro Basílio Alberto de Sousa Pinto ${ }^{2}$, seu tutor, e respectivo irmão, Doutor Rodrigo Ribeiro de Sousa Pinto, lente de matemática, esposa e filhas, o reitor da Universidade de Coimbra e família, o secretário da Universidade, vários lentes, além de muitas outras pessoas. À chegada - prosseguia aquele periódico - esperavam a jovem educanda e tão "lusidia" companhia, toda a comunidade docente e discente do colégio, a quem a superiora, num gesto de deferência e de boas-vindas, obsequiou com uma recepção musical, seguida por "um chá esplêndido".

Nem todas as meninas teriam, aquando do seu ingresso no colégio das Ursulinas, esta recepção principesca... Porém, se esta é bem esclarecedora quanto ao prestígio do eminente jurista Coelho da Rocha, a quem a comunidade académica quis desta forma prestar uma última homenagem, igualmente elucida sobre o elitismo da clientela do Real Colégio Ursulino das Chagas, patente na forma de tratamento "Sra. D." dado a uma criança tão jovem... O uso deste título honorífico 
que é, aliás, uniformemente aplicado a todas as alunas, qualquer que seja a sua idade, constitui um indicador significativo da origem das educandas.

Com efeito, a estada neste colégio era apenas acessível a uma pequena minoria de raparigas oriunda dos meios privilegiados da nobreza ou da média e alta burguesia para quem a instrução, à maneira iluminista, era um sinal distintivo. O ensino católico ali ministrado não se destinava a proporcionar uma eventual promoção social ou os meios indispensáveis a uma futura independência financeira mas, tão-só, a confirmar um estatuto. Adequado ao meio social a que pertenciam as educandas, bem como ao papel da mulher na sociedade, tal como, ao tempo, o entendiam certos meios ilustrados e a doutrina social da Igreja, o ensino no Real Colégio Ursulino esforçava-se por inculcar nas raparigas o amor pela religião e pela virtude, pela disciplina e pelos hábitos de trabalho, assim como o respeito pelos superiores, de modo a formar "verdadeiras mães de família, piedosas e devotas, que saibam conciliar e reunir os deveres religiosos com os do seu estado e profissão"3. Saber como é que estes objectivos se concretizavam e se reflectiam no dia-a-dia do colégio assim como avaliar do contributo deste estabelecimento de ensino como agente de socialização são algumas das questões a que se tentará dar resposta neste estudo.

A análise histórica do ensino congreganista feminino no século XIX está ainda em grande parte por fazer, no nosso país, sendo em escasso número as monografias sobre colégios ou escolas católicas ${ }^{4}$. A falta de fontes directas, a dificuldade de acesso aos arquivos privados dos institutos religiosos e a própria dispersão dos fundos documentais, em consequência da extinção das ordens religiosas e das disposições tomadas logo após a implantação da República, tornam árdua, senão mesmo impossível em alguns casos, a tarefa de reunir um corpo suficiente de fontes que possibilite acompanhar o itinerário escolar das educandas dos estabelecimentos católicos e avaliar com rigor da qualidade da instrução neles ministrada. A estes problemas de fundo acrescem as limitações decorrentes da própria organização do ensino privado católico. A sua estrutura extremamente descentralizada, por oposição ao ensino público, e a ausência de uma cultura do registo escrito (Lagrée, 1995: 26-31), entre outros factores, reflectem-se na escassez de fontes arquivísticas, obrigando o historiador a um paciente trabalho de reconstituição histórica de modo a "fazer falar o silêncio" (Fayet-Scribe, 1990: 7), bem como à humildade perante as conclusões. Não admira por isso que o ensino religioso feminino permaneça um domínio pouco estudado e que ainda lhe não tenha sido prestada a devida atenção. 


\section{AS FONTES E SEUS PROBLEMAS}

As informações disponíveis sobre o Real Colégio Ursulino das Chagas não fogem a esta caracterização geral. Com excepção de alguma documentação impressa, avulsa e heterogénea (textos normativos, regulamentos internos, programas, legislação, notícias esporádicas na imprensa ou em revistas especializadas, etc.), são em número reduzido as fontes manuscritas, em particular as que colijam dados suficientemente contínuos que permitam a sua exploração sistemática.

De entre a documentação rastreada figuram escrituras públicas, em particular de "prestação de alimentos", insertas em livros notarais que se encontram depositados no Arquivo da Universidade de Coimbra ${ }^{6}$, bem como um livro de assentos de despesas de alunas do Colégio com a designação de Boletins trimensais das despesas eventuais das Educandas do Real Colégio Ursulino, correspondente ao período de 1874 a 1880, conservado na Biblioteca Geral da Universidade de Coimbra. Trata-se de fontes que se complementam, visto que se destinavam a materializar o ingresso no Colégio. A admissão neste estabelecimento de ensino impunha, entre outras condições de acesso ${ }^{7}$, a redaç̧ão de uma escritura pública "à custa dos paes ou protectores das educandas", na qual estes se obrigavam "com fiador conhecido e abonado" ao pagamento das pensões e mais despesas. As despesas, conforme especificavam os programas publicados na imprensa, eram de dois tipos: as despesas certas, cobradas pelo piso, roupa do refeitório, alimentos e enfermaria, pagas por ocasião da escritura notarial e da saída final, e as despesas eventuais, provenientes de remédios e juntas de médicos, livros, preparos e instrumentos necessários para o ensino, lavagem e conserto de roupa, correspondência e renovação do calçado, pagas, em princípio, trimestralmente e variando de aluna para aluna de acordo com os respectivos gastos.

$\mathrm{O}$ interesse destes documentos para o conhecimento desta casa religiosa é indiscutível. As escrituras notariais, na ausência de registos nominativos das alunas, constituem a única fonte de informação sobre o recrutamento das educandas, especificando a data da sua admissão e, eventualmente, a origem social e geográfica. Quanto aos Boletins trimensais [...], pelos aspectos materiais que evocam, desde os objectos pessoais das educandas aos uniformes, passando pelos trabalhos escolares ou pelas brincadeiras de entrudo, entre tantos outros assuntos, são um importante testemunho do quotidiano. Têm, no entanto, o inconveniente de apenas se reportarem a parte das alunas, tão-só aquelas que se encontravam na situação de internas durante o período de 1874 a 1880 . Com efeito, as despesas eventuais contabilizadas dizem respeito a 41 educandas, as quais ingressaram no colégio entre 1858 e 1880 . Estas datas foram obtidas a partir das escrituras notariais que, em princípio, formalizam a admissão. Ora, o levantamento exaustivo das escrituras de "prestação de alimentos" feitas ao Real Colégio Ursulino das 
Chagas, de Coimbra, permitiu verificar que, no período de 1858 a 1880 , ingressaram nesta instituição cerca de 201 meninas, pelo que se poderá concluir da fraca percentagem de jovens referidas neste documento $(16,2 \%)^{8}$. O número de admissões deveria, no entanto, ser superior ao registado, dado que algumas jovens parecem ter entrado no colégio sem que os seus encarregados de educação tenham previamente formalizado a escritura ou, se o fizeram, recorreram a notários sediados fora dos limites da cidade de Coimbra, o que é impossível detectar.

Cada uma das fontes recenseadas é, por conseguinte, insuficiente para uma análise da sociologia do corpo discente ou da própria educação feminina. Conjuntamente permitem concretizar uma aproximação às práticas pedagógicas desenvolvidas e reconstituir alguns aspectos do dia-a-dia no Real Colégio Ursulino das Chagas.

O estudo deste tema exige, no entanto, que se faça um breve historial do Colégio, incidindo em particular no período da sua instalação na cidade de Coimbra9.

Em 1874, data de início dos Boletins trimestrais [...] e ponto de partida desta investigação, completavam-se cento e vinte e seis anos sobre a sua fundação, na vila de Pereira, em 1748, tendo nos últimos vinte anos funcionado já em Coimbra. Com efeito, em 1848, na sequência de febres de origem palúdica, as religiosas Ursulinas abandonam aquela localidade dos campos do Mondego, instalando-se provisoriamente no Convento de Sánta Ana, em Coimbra, das eremitas de Santo Agostinho, onde irão permanecer durante cerca de três anos. Em 1851, na sequência do contencioso que oporá o Estado à Faculdade de Medicina a propósito do edifício de S. José dos Marianos, que à data funcionava como hospital, este é entregue às religiosas de Santa Úrsula para aí ser instalado o Colégio. $O$ caso é seguido com atenção pela imprensa local, em particular pelos jornais $O$ Observador e $O$ Liberal do Mondego, de tendências conservadora e liberal, respectivamente, que, numa leitura pouco neutral da questão, a inserem na problemática mais vasta da recuperação de influência por parte da Igreja católica na sociedade, sobretudo após a assinatura da Concordata com a Santa Sé em 1848, posicionando-se a seu favor ou contra. Contudo, subjacente ao debate ideológico, encontram-se argumentos de peso em abono da instalação do Colégio em sede própria. A necessidade de implantar um sistema de ensino "de qualidade" para o sexo feminino na cidade de Coimbra, cuja ausência era lamentada por vários sectores da opinião pública, e a exiguidade das instalações no convento de Santa Ana, decorrente da coexistência das duas comunidades religiosas no mesmo edifício, pesaram na decisão tomada. Os apoios vieram das instâncias oficiais e do poder municipal, empenhados no desenvolvimento do ensino privado feminino, dadas as insuficiências do sector público nesta matéria, bem como da própria monarca e do bispo de Coimbra, D. Manuel Bento Rodrigues. A rainha $\mathrm{D}$. Maria II colocaria, de certa forma, um ponto final nesta polémica, 
ao declarar-se, em 1852, protectora oficial do Real Colégio Ursulino das Chagas, contribuindo, assim, para o seu relançamento.

A instalação em S. José dos Marianos abre uma nova etapa na vida deste estabelecimento de ensino. Ao procurar ir ao encontro do interesse que a educação feminina suscita na novel sociedade liberal e ao tentar adequar os planos de estudo com a reforma do ensino promulgada por Costa Cabral, em 1844, o Colégio melhora o nível dos seus estudos, renovando os curricula pela inclusão de um leque mais alargado de disciplinas. A educação e a instrução de meninas permanece, no entanto, como o fim último deste Instituto. As novas exigências educativas e o aumento do número de educandas obrigariam a alterar alguns aspectos do Regulamento das Ursulinas, em particular no que concerne às práticas religiosas e aos respectivos horários, de modo a que as religiosas pudessem, "na maior perfeição", "abraçar os ofícios de Marta e Maria, sem que reciprocamente se embaracem" (Lemos, 1862: 8). Nos anos seguintes não se registam modificações significativas na estrutura escolar implantada, com excepção da abertura de uma classe para alunas externas ${ }^{10}$, em 1883 , que se vem adicionar às classes já existentes: a de meninas internas, pensionistas, e a de meninas pobres, gratuita, imposta por legislação de 1789.

É, pois, o dia-a-dia deste estabelecimento escolar que se tentará surpreender no início da década de setenta do século passado. Mas deixemos os documentos falar e entremos discretamente no Real Colégio Ursulino das Chagas...

\section{AS "MENINAS DAS URSULINAS": BREVE ESBOÇO SOCIOLÓGICO}

"[...] Sendo o seu maior desejo que sua filha (ou protegida) receba a melhor educação, e sabendo que ela se adquire neste Real Colégio para o que as Ex. mas Religiosas empregam as possíveis diligências, por isso requer a admissão da sua filha". É com estas palavras que principiam as escrituras notariais que oficializam o acto de admissão no Real Colégio Ursulino das Chagas de Coimbra. O prestígio deste pensionato, que o formulário jurídico deixa transparecer, fundamenta-se num longo passado dedicado ao ensino feminino, na protecção oficial da rainha D. Maria II e do bispo de Coimbra, na qualidade da instrução ministrada e, naturalmente, numa clientela seleccionada. Com efeito, a maioria dos pais ou tutores que inscrevem as suas filhas ou protegidas neste colégio pertencem aos estratos médios ou médios superiores da sociedade, apesar da alta taxa de indeterminação $(34,1 \%)$ retirar algum rigor às conclusões (Quadro I). 


\section{Quadro I}

\section{CATEGORIAS SÓCIO-PROFISSIONAIS DOS PAIS, TUTORES E FIADORES DAS EDUCANDAS INTERNAS (1874-1880)}

\begin{tabular}{|lcccc|}
\hline & Pais/Tutores & Fiadores \\
& $\mathrm{N} .^{\circ}$ & $\%$ & $\mathrm{~N}^{\circ}$ & $\%$ \\
Universitários & 2 & 4,9 & 15 & 36,6 \\
Prof. Liberais & 9 & 22 & 2 & 4,9 \\
Militares & 3 & 7,3 & & \\
Nobres & 2 & 4,9 & & \\
Eclesiásticos & & & 6 & 14,6 \\
Funcionários públicos & 1 & 2,4 & 1 & 2,4 \\
Proprietários & 7 & 17,1 & 1 & 2,4 \\
Comerciantes e industriais & 3 & 7,3 & 5 & 12,2 \\
Sem identificação & 14 & 34,1 & 11 & 26,8 \\
& & & & \\
Total & 41 & 100 & $4 I$ & 99,9 \\
\hline
\end{tabular}

Fonte: Boletins trimensais das despesas eventuais das Educandas do Real Colégio Ursulino ( 1874 a 1880).

Profissionais liberais (22\%), com destaque para magistrados e advogados, bem como proprietários $(17,1 \%)$ são as categorias sócio-profissionais mais representadas. Só uma pequena minoria pertence aos meios privilegiados da nobreza $(4,9 \%)$ ou da intelligentzia conimbricense $(4,9 \%)$. Porém, o prestígio de um nome ilustre ou de um título nobiliárquico constitui uma "carta de recomendação" que atrai clientela, desempenhando um papel importante na reputação deste pensionato. A própria imprensa local contribui para a sua notoriedade, ao evocar, nas páginas dos jornais, a admissão desta ou daquela menina de sangue azul ou da filha de um conceituado docente universitário, bem como da passagem pela cidade de Coimbra dos ilustríssimos progenitores...

A selectividade social é reforçada pelo custo do internato, cuja pensão mensal, na década de setenta, era de $10 \$ 000$ réis. Acrescem-lhe $24 \$ 200$ réis da matrícula, montante que resulta do somatório das despesas do piso e da propina para o refeitório (19 $\$ 200$ réis), com as propinas para as classes ( $2 \$ 000$ réis) e para a enfermaria (3\$000 réis), sendo esta última quantia liquidada no momento da saída final da educanda. Trata-se de uma tarifa mensal que equivale ao dobro da praticada no

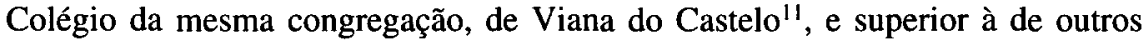
estabelecimentos religiosos que também promoviam a instrução, tanto a femi- 
nina ${ }^{12}$, como a masculina ${ }^{13}$. O confronto do preço médio do internato com o de alguns salários urbanos realça o elitismo da instituição. Em 1876, um contínuo da Sociedade Terpsychore Conimbricense ganhava, por ano, $57 \$ 000$ réis, ou seja, cerca de metade da pensão anual do Colégio ${ }^{14}$. Um farmacêutico alcançava os $162 \$ 000$ réis anuais, mas só à custa de grandes sacrifícios conseguiria manter uma filha no Real Colégio Ursulino das Chagas de Coimbra ${ }^{15}$. As famílias com uma situação económica desafogada eram, na verdade, as únicas com possibilidade para fazer face aos honorários praticados, sendo estes ainda agravados com as despesas eventuais e os custos do"enxoval".

As primeiras despesas implicavam, para a maioria das educandas $(75,4 \%)$, o pagamento mensal de uma soma que, em média, oscilava entre os $1 \$ 001 \mathrm{e}$ os $3 \$ 000$ réis (Quadro II), despendida em grande parte com bens pessoais (Quadro III), em particular vestuário, calçado e respectiva manutenção (Quadro IV). As restantes despesas influíam pouco na soma gasta, com excepção da lavagem e da engomagem da roupa.

\section{Quadro II}

"DESPESAS EVENTUAIS": MÉDIAS MENSAIS

\begin{tabular}{|lrccc|}
\hline Classes em réis & $\mathrm{N}^{\circ}$ & $\%$ & Quantias & $\%$ \\
$<1000$ & 2 & 4,9 & 1760 & 1,9 \\
$1001-2000$ & 21 & 51,2 & 33133 & 35,1 \\
$2001-3000$ & 10 & 24,4 & 26389 & 28 \\
$3001-4000$ & 3 & 7,3 & 9993 & 10,6 \\
$4001-5000$ & 4 & 10 & 17931 & 19 \\
$>5001$ & 1 & 2,4 & 5119 & 5,4 \\
Total & 41 & 100 & 94325 & 100 \\
\hline
\end{tabular}

Fonte: Boletins trimensais das despesas eventuais das Educandas do Real Colégio Ursulino (1874 a 1880). 


\section{Quadro III \\ DESPESAS EVENTUAIS: REPARTIÇÃO POR CATEGORIAS (VALORES PERCENTUAIS)}

\begin{tabular}{|c|c|}
\hline Categorias & $\%$ \\
\hline 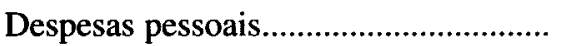 & 58,8 \\
\hline 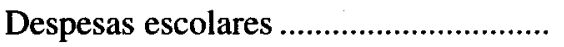 & 39,3 \\
\hline Correio & 1,49 \\
\hline 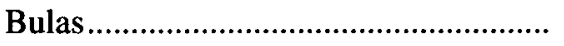 & 0,16 \\
\hline 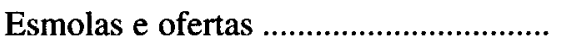 & 0,22 \\
\hline 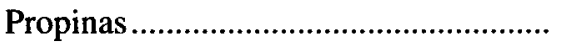 & 0,38 \\
\hline Sem identificação .................................. & 0,06 \\
\hline
\end{tabular}

A escassa importância que as propinas "para a saída final" revestem, no cômputo geral das despesas $(0,38 \%)$, justifica-se pelo facto de apenas três educandas as incluírem nos respectivos róis. Se tomarmos à letra o Regulamento que exigia a sua liquidação no termo do internato, destinando-se esta quantia à enfermaria, poder-se-á concluir que Maria Augusta Mourão, Laura Clementina de Castro e Florinda Josefa Rodrigues terminaram os seus estudos respectivamente em Abril e Julho de 1876, e Agosto de 1880, após dois anos como internas.

\section{Quadro IV \\ DISCRIMINAÇÃO DAS DESPESAS PESSOAIS: VALORES PERCENTUAIS}

Vestuário. 51,4

Calçado e sua manutenção 26,1

Lavagem e engomagem da roupa

Botica 9,43

Utensílios para uso próprio 6,06

Objectos de adorno pessoal 3,73

Alimentação 1,9

Higiene 0,3

Quanto aos custos do enxoval são mais difíceis de contabilizar, a não ser pontualmente. Por "enxoval" entendia-se a roupa de uso pessoal e os equipamentos do refeitório, do dormitório e de higiene requeridos pelo colégio, sendo devolvi- 
dos no momento da saída final. Por volta dos anos 1860 , este compunha-se do uniforme, uma cama completa, com barra de ferro, pano para os cortinados, lavatório com saboeira, uma cadeira grande e duas pequenas, talher, guarda-roupa ou dois baús e o "mais [...] que quiserem, mas que seja suficiente para o aceio e decencia" ${ }^{16}$. Os preços de alguns destes bens, quando fornecidos pela instituição, podem ser deduzidos da relação das despesas eventuais. $O$ do uniforme rondaria os $9 \$ 000$ réis, quantia que incluía a sua confecção, e o de certas peças de mobília e utensílios para uso pessoal cerca de $11 \$ 000$ réis (Quadro $\mathrm{V}$ ).

\section{Quadro V \\ PREÇO MÉDIO DE ALGUMAS PEÇAS DO “ENXOVAL” (EM RÉIS)}

\begin{tabular}{|c|c|}
\hline \multicolumn{2}{|l|}{ Uniforme } \\
\hline 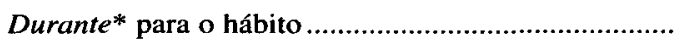 & 4185 \\
\hline 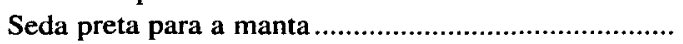 & 2586 \\
\hline 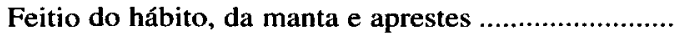 & 1124 \\
\hline Véu preto & 1043 \\
\hline 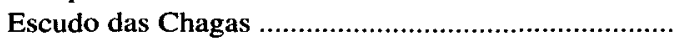 & 400 \\
\hline Total & 9338 \\
\hline \multicolumn{2}{|l|}{ Dormitório } \\
\hline Cobertor ...................... & 2800 \\
\hline Manta de lã & 863 \\
\hline Coberta para a cama & 3700 \\
\hline Almofada & 300 \\
\hline Travesseira/travesseirinha & 1010 \\
\hline Bacia de cama & 120 \\
\hline 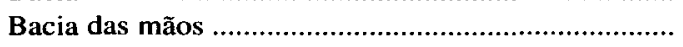 & 143 \\
\hline Saboeira & 200 \\
\hline 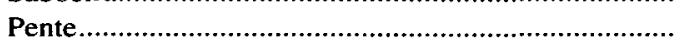 & 130 \\
\hline Pente fino & 290 \\
\hline Pente de alisar & 100 \\
\hline 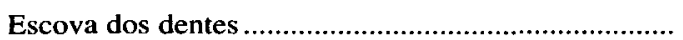 & 122 \\
\hline Escova das unhas & 200 \\
\hline Total & 9978 \\
\hline Refeitório & \\
\hline Louça para seu uso & 559 \\
\hline Caneca & 35 \\
\hline (1) & 140 \\
\hline Copo para a água & 80 \\
\hline 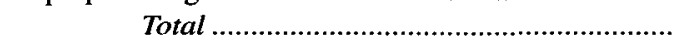 & 814 \\
\hline 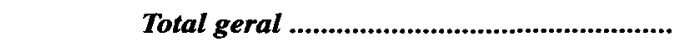 & 20130 \\
\hline
\end{tabular}


Feitas as contas, a matrícula de uma jovem no Real Colégio Ursulino das Chagas de Coimbra obrigaria os seus familiares ou tutores a desembolsarem, pelo menos no $1^{\circ}$ ano, uma quantia não inferior a $180 \$ 000$ réis. Trata-se de um montante elevado, cuja solvabilidade as religiosas tentavam assegurar mediante a exigência do pagamento adiantado da mensalidade no princípio de cada mês, em metal sonante "sem curso forçado"17, e da apresentação de um fiador idóneo. A categoria social destes era, de um modo geral, mais elevada do que a dos próprios pais ou tutores das educandas, sobressaindo lentes da Universidade $(36,6 \%)$ e eclesiásticos que ocupavam posições de relevo na diocese conimbricense $(14,6 \%)^{18}$, entre os quais o bispo de Coimbra, D. Manuel Correia de Bastos Pina ${ }^{19}$. Algumas crianças parecem beneficiar do estatuto de aluna gratuita ${ }^{20}$, o que, porém, não as isentava do pagamento das despesas eventuais. $O$ parentesco com "mestras educandas" ou com destacados elementos da hierarquia católica parece justificar alguns destes $\operatorname{casos}^{21}$.

Os preços praticados não dissuadiam, por conseguinte, as clientelas de optarem por este internato. Estas provinham de quase todo o país, embora em maior número da região centro (Quadro VI). Mais de $75 \%$ das educandas residiam nos distritos de Aveiro, Castelo Branco, Guarda, Lisboa, Viseu e sobretudo no de Coimbra que, só por si, fornecia $29,3 \%$ das pupilas.

Trata-se de jovens que procedem, na sua maioria, de meios rurais $(51,2 \%)^{22}$, sem possibilidades de beneficiarem no local de residência ou no domicílio familiar de uma educação adequada ao seu nascimento. Na verdade,as alternativas à educação doméstica não eram, ao tempo, muito variadas.

\section{Quadro VI \\ LOCAL DE RESIDÊNCIA DOS PAIS OU TUTORES DAS EDUCANDAS INTERNAS (1874-1880)}

\begin{tabular}{|l|r|r|}
\hline \multicolumn{1}{|c|}{ Distritos } & $\mathrm{N}^{\circ}$ & $\%$ \\
\hline Aveiro & 4 & 9,8 \\
\hline Castelo Branco & 1 & 2,4 \\
\hline Coimbra & 12 & 29,3 \\
\hline Évora & 1 & 2,4 \\
\hline Guarda & 5 & 12,2 \\
\hline Lisboa & 2 & 4,9 \\
\hline Portalegre & 2 & 4,9 \\
\hline Porto & 2 & 4,9 \\
\hline Viseu & 5 & 12,2 \\
\hline Sem identificação & 7 & 17,1 \\
\hline Total & 41 & 100 \\
\hline
\end{tabular}


Para além das escolas primárias oficiais que, em princípio, se destinavam a crianças de meios humildes, subsistiam escolas congreganistas a funcionar em conventos, recolhimentos ou instituições similares, bem como em colégios. O número destes, em 1875, a crermos no levantamento feito por Aristides Abranches, era muito reduzido, limitando-se a 7 para todo o continente ${ }^{23}$. Mesmo admitindo que esta estimativa peca por defeito, como é provável ${ }^{24}$, a rede de instrução particular do sexo feminino afigura-se muito limitada, restringindo as hipóteses de escolha. $O$ recurso ao pensionato parece ser, no entanto, um expediente utilizado com maior frequência por encarregados de educação de crianças que tiveram a fatalidade de perder um ou os dois progenitores. Esta hipótese é sugerida pelo número relativamente elevado de órfãs entre as educandas $(13-31,7 \%)^{25}$. É, aliás, entre estas crianças que predominam os grupos de irmãs, bem como as estadias que se prolongam por períodos superiores a 5 anos (Quadro VII) ${ }^{26}$.

\section{Quadro VII \\ PERMANÊNCIA NO REAL COLÉGIO}

\begin{tabular}{|l|c|c|c|c|}
\hline & \multicolumn{2}{|c|}{$\begin{array}{c}\text { Educandas } \\
\text { (Total) }\end{array}$} & \multicolumn{2}{|c|}{$\begin{array}{c}\text { Educandas } \\
\text { órfãs }\end{array}$} \\
\hline & $\mathrm{N}^{\circ}$ & $\%$ & $\mathrm{~N}^{\circ}$ & $\%$ \\
Até 6 meses & 3 & 7,3 & & \\
7 meses -1 ano & 2 & 4,9 & 1 & 50 \\
13 meses - 2 anos & 4 & 9,8 & 2 & 50 \\
25 meses - 5 anos & 15 & 37 & 6 & 40 \\
61 meses - 10 anos & 8 & 20 & 4 & 50 \\
$>16$ anos & 1 & 2,4 & & \\
Sem identificação & 8 & 20 & & \\
\hline
\end{tabular}

Fonte: Boletins trimensais das despesas eventuais das Educandas do Real Colégio Ursulino (1874 a 1880) e escrituras notariais.

Porém, salvo estes casos que resultam de circunstâncias excepcionais, a duração média da permanência no Colégio era de 3 a 4 anos, não necessariamente consecutivos. Um tal regime não favorecia uma aprendizagem intelectual aprofundada, nem sequer permitia completar a escolaridade elementar, que era de 4 anos, e muito menos a complementar, de 6 anos. Adequa-se, no entanto, ao modelo educativo adoptado pelas classes superiores de Oitocentos relativamente às suas filhas, o qual consistia no seu envio para um internato durante um ou dois anos, a fim de serem preparadas para a 1. ' Comunhão (Mayeur, 1974a: 422-423; Mayeur, 1979b: 38). A formação do carácter e da sensibilidade da futura esposa e mãe de 
família condicionavam a duração e o tipo de instrução a ministrar, não se pretendendo formar intelectuais nem raparigas profissionalmente qualificadas. Trata-se, porém, de uma estadia superior às registadas em estabelecimentos similares setecentistas $^{27}$, mas inferior à exigida aos rapazes ou mesmo àquela que vigorava em alguns pensionatos femininos laicos do século $\mathrm{XIX}^{28}$.

A brevidade da instrução era ainda agravada pelas interrupções a que esta estava sujeita ${ }^{29}$. Em rigor, as saídas temporárias não eram permitidas em caso algum, inclusive a "pretexto de férias, excepto em caso de moléstia com declaração por escrito do Facultativo"(Abreu, 1857: 206), consentindo-se tão-só nas visitas de familiares em dias santificados ou feriados do Colégio ${ }^{30}$. A prática colegial era, no entanto, mais flexível, demonstrando as religiosas Ursulinas uma certa tolerância nesta matéria. Com efeito, se identificarmos as interrupções na redacção dos Boletins com saídas temporárias, seremos levados a concluir que a grande maioria das alunas, numa época ou outra, por temporadas variáveis nunca inferiores a um mês e superiores a um ano, se ausentaram do colégio. A arbitrariedade na periodização caracteriza estas "saídas", sendo raras as alunas que as desfrutavam no mês de Setembro, no termo do ano escolar, após os exames de Agosto. Antónia Luísa Canais de Sousa Seco é, neste aspecto, a excepção que confirma a regra visto que, de 1874 a 1879, sistematicamente no mês de Setembro se ausentava do colégio, provavelmente para "banhos". A noção de férias, desconhecida no Antigo Regime (Bricard, 1985: 142), ainda não entrara nos hábitos da clientela do colégio.

Falta de rigor verifica-se também nas admissões das alunas que, ao invés de se concentrarem no período imediatamente anterior ao início do ano escolar a 1 de Outubro, se distribuem por todo o ano. Assim, das 33 educandas com registo de matrícula, $11(33,3 \%)$ foram admitidas em Outubro, 9 (27,3\%) em Maio, $5(15,2 \%)$ em Abril, $4(12,1 \%)$ em Novembro, repartindo-se as restantes pelos meses de Janeiro, Junho, Julho e Dezembro.

A impressão de desorganização escolar que se colhe desta estrutura educativa é reforçada pela falta de uniformidade nas idades de ingresso, admitindo-se crianças dos 7 aos 15 anos, podendo estas permanecer no Colégio até à sua maioridade, ou seja, 25 anos (Abreu, 1857: 202; Lemos, 1862: 39). Embora a falta de informação não permita especificar a idade das alunas inscritas ${ }^{31}$, não será difícil supor a coabitação de crianças de diferente maturidade, o que acarretaria alguns transtornos na organização escolar e na aprendizagem. Na realidade, as religiosas procuravam atenuar este inconveniente separando as classes por grupos etários e por instalações. Contudo, as dificuldades logísticas e sobretudo a tentativa de recriação de um ambiente familiar, caro ao espírito da Ordem, subvertia este sistema hierárquico, consentindo-se que, pelo menos, grupos de irmãs, qualquer que fosse a sua idade, permanecessem juntos. 
Maiores precauções suscitavam os contactos com crianças de estratos sociais inferiores, em particular "as meninas pobres", a quem as Ursulinas ministravam gratuitamente ensino e educação religiosa. O receio de promiscuidade social, o "horror das misturas" nas palavras de Martine Sonnet (1987: 144), impunham a implantação de um sistema discriminatório baseado numa rígida separação de espaços $^{32}$. As crianças nunca se encontravam excepto no dia da cerimónia da $1^{\text {a }}$ Comunhão ${ }^{33}$, em que se admitia, quer na celebração religiosa, quer no almoço que se lhe seguia, o convívio. A rejeição dos valores democráticos, tanto em termos práticos como ideológicos, adequava-se ao espírito segregacionista do século XIX, constituindo o isolamento das pensionistas uma garantia de moralidade que reforçava a confiança nas religiosas.

No entanto, a "classe das pobrezinhas", como tantas vezes era designada, inseria-se na estratégia educativa do Colégio permitindo desenvolver actividades de assistência pública, cujo exercício constituía um dever das mulheres das classes elevadas, adequando-se às funções de "mediadora social" que se thes atribuía (Lelièvre e Lelièvre, 1991:111-112). Assim, anualmente, na QuintaFeira Santa, as pensionistas do Colégio serviam às "alunas pobres externas" um "jantar de caridade" 34 . Trata-se de um procedimento normal em colégios católicos do século XIX (Bricard, 1985: 142), consistindo numa iniciação às práticas caritativas (Fayet-Scribe, 1990: 40), as quais eram, de uma forma geral, encorajadas, detectando-se nas despesas eventuais de algumas jovens pequenos quantitativos destinados a "esmolas para os pobres" ou "esmolas para o jantar dos pobres".

Afinidades de carácter pedagógico aproximam, pois, o Real Colégio Ursulino das Chagas, de Coimbra, de instituições congéneres estrangeiras. Fundamentam-nas a coincidência na defesa dos valores católicos e uma certa identidade em torno dos princípios que deveriam estruturar a educação de uma jovem das classes elevadas. O próprio internacionalismo da ordem e a sua permeablidade a influências exteriores, apoiado no intercâmbio das religiosas, contribuíram para a difusão de um discurso ideológico comum. Com frequência se deslocavam a Coimbra freiras estrangeiras da congregação, a fim de leccionarem esta ou aquela disciplina ${ }^{35}$, dando azo a uma salutar permuta de experiências e de conhecimentos, com o que beneficiavam as educandas e o prestígio do colégio.

\section{AS HORAS E OS DIAS NO COLÉGIO}

A vida quotidiana no interior do Colégio obedecia a regras estritas que, pelo menos em teoria, não admitiam transgressão. A separação por grupos etários e a vigilância apertada das alunas estruturavam o edifício pedagógico que considerações de ordem moral fundamentavam. "A boa educação das meninas - explicita- 
vam os Regulamentos - depende das relações quotidianas da Mestra com as discípulas, e destas entre si: a convivência das meninas, debaixo das vistas de uma ilustrada, prudente e virtuosa Mestra, corrige muitos defeitos, que nascem de se estar só; amacia a rudeza do carácter, modifica os caprichos; tempera as iras; acostuma à beneficência pela permutação de pequenos serviços e obséquios entre as condiscípulas; e estimula para o bem" (Lemos, 1862: 38).

Através do acompanhamento constante procurava-se proteger as crianças de influências deletérias, a fim de salvaguardar a futura moralidade familiar. $O$ receio de preversão das almas mais inocentes pelas "más companhias" e os esforços da individualização infantil numa época em que a adolescência suscitava uma generalizada desconfiança, aconselhavam a separação das meninas por classes. Estas, sugestivamente designadas por "familias ou educandados parciaes", estavam organizadas por escalões etários: dos 7 aos 10 anos, dos 10 aos 15 e dos 15 aos 25 anos (Lemos, 1862: 41).

Uma vez formalizada a admissão, cada nova educanda era encaminhada para a classe respectiva e confiada aos cuidados de uma Mestra directora, acolitada, em caso de necessidade, por uma subordinada. Retiradas do lar paterno aos 9,10 ou 11 anos, o Colégio será, para muitas crianças, a sua segunda casa e a Mestra directora uma "segunda mãe". Com efeito, tentar-se-á recriar em cada classe um ambiente familiar, cabendo às Mestras directoras desempenhar o papel de mães: "sempre carinhosas e zelosas" (Lemos, 1862: 43-44).

O modelo da mãe educadora, exaltado no século XIX (Fraisse, 1976: 19591960; Arnold, 1984: 177-184), norteia a acção pedagógica das religiosas. Nesta medida, compete-lhes inspirar nas educandas "por palavras, e com os exemplos, o amor de Deus e do próximo, a prática de todas as virtudes cristãs", instruí-las "nas boas maneiras, com que deverão apresentar-se na sociedade [...] nos deveres que $[\ldots]$ terão para cumprir nas diferentes ocasiões e circunstâncias $[\ldots]$ nos princípios e práticas de um bom governo e trato de casa, para que possam ser depois boas donas dela" e ainda dar-lhes "lições de boa creação", cuidando "para que se correspondam com seus pais e famílias, principalmente se estas residirem fora de Coimbra", ensinando-lhes "as regras de civilidade, que nas cartas se devem observar; e emendarão os erros e defeitos que elas escreverem" (Lemos, 1862: 44).

Os documentos compulsados não permitem aferir da sinceridade dos sentimentos maternais expressos ou precisar o tipo de relacionamento estabelecido entre as docentes e as educandas. Não será, no entanto, difícil supor que, em alguns casos, uma profunda estima mútua as uniria e certas crianças poderiam subscrever as palavras de Josephina Neuville que se referia às religiosas do pensionato parisiense, onde passara parte da sua infância, como "as minhas queridas damas do Sacré Coeur" (1864: 85). O inverso também é válido. $O$ afastamento da casa paterna e a disciplina severa também poderiam induzir a rebeldia 
e o espírito de revolta, assunto caro a uma certa imprensa republicana que se comprazia em denunciar "os gravissimos inconvenientes da educação dos conventos"36.

Os dias sucediam-se, semelhantes uns aos outros, entrecortados pela cadência regular das actividades. Os Regulamentos são, aliás, mais prolixos quanto aos procedimentos morais a adoptar do que quanto às previsões horárias, cuja calendarização competia às Directoras ${ }^{37}$. Insistia-se sobretudo na "ordem", na "decência", no "silêncio", na "submissão", na "modéstia", no "decoro", no "respeito nos templos", mas nada se especificava quanto aos aspectos práticos da organização diária (horários e composição das refeições, cuidados de higiene, etc.). As normas regulamentares permitem, no entanto, reconstituir o dia-a-dia no Colégio, desde o amanhecer até ao anoitecer. "Levantar-se-hão as educandas depois da Comunidade, á hora que determinar a Superiora, conforme as estações". "Decentemente vestidas", dirigiam-se para o Oratório para, em comum, "fazer [...] as orações vocaes da manhã, as quais uma das Educandas recitará em voz alta e pausada, e as outras repetirão em voz submissa". Em seguida, assistiam à missa, após o que se dirigiam ao refeitório, para almoçar. À hora "costumeira" davam início às aulas que prosseguiam depois do jantar. Nas horas vagas, trabalhavam "nas suas costuras" ou estudavam as lições, não se permitindo "que andem ociosamente vagueando ou correndo pelos dormitórios". Os tempos de recreação eram breves, geralmente logo após as refeições. Ao anoitecer, depois do toque das Avé-Marias, rezavam nos seus Educandados a "Coroa e a Ladainha de Nossa Senhora". À "hora competente" retiravam-se para dormir (Lemos, 1862).

Os dias decorriam, assim, entre o dormitório, o refeitório, a capela, as salas de aulas, o claustro e o jardim, que funcionava como recreio, e onde cada aluna tinha um pequeno canteiro de flores do qual cuidava pessoalmente ${ }^{38}$.

Raramente saíam e os poucos passeios que davam circunscreviam-se à zona da "cerca" do Colégio, nos dias feriados, acompanhadas pelas respectivas mestras. Só em ocasiões excepcionais, como durante a visita de D. Maria II a Coimbra, em 1852, se deslocavam ao centro da cidade ${ }^{39}$. Concebido como uma forma de isolamento face ao mundo exterior, o quotidiano colegial era decalcado sobre a vida monástica, com a qual mantinha muitas afinidades. Inclusive as próprias visitas de familiares não eram incentivadas, dando-se preferência ao relacionamento epistolar. Por esse motivo quase todas as educandas incluíam nas suas despesas trimestrais gastos com "estampilhas" e, eventualmente, com "encomendas". Pela mesma razão, as somas despendidas com o "correio" eram superiores aos gastos com as "ofertas" que, de uma forma geral, consistiam em pequenos "mimos" (bolos, bolachas, doces, estampas...), destinados a presentear os parentes próximos aquando das visitas. 
Quanto às instalações propriamente ditas (refeitórios, dormitórios, etc.), os documentos são pouco loquazes, insistindo-se sobretudo no seu carácter salubre e higiénico. "As camaratas, aonde dormem as Educandas - descrevia-se por volta de 1853 - estão em dois belos salões, espaçosos, bem expostos e sadios: ficam juntos aos dormitórios das Religiosas, mas deles separados com portas sobre si [...], as camas das meninas, simetricamente dispostas, e cobertas para resguardo e decência [...]. Além destes salões, há quartos, destinados para o mesmo fim" (Pinto, s.d.:11-12). Algumas informações extraídas do rol das despesas permitem reconstituir o mobiliário desta dependência. Este consistia em camas de ferro, individuais, separadas entre si por um cortinado ou uma espécie de biombo, cadeiras de palhinha, guarda-roupas, baús e mesas de cabeceira com "um santo encaixilhado" em cima. Uma decoração sumária evocativa de um ambiente austero, quase espartano, cujo conforto deixava muito a desejar... O frio, sobretudo no inverno, quando estudavam, seria difícil de suportar mesmo socorrendo-se de "mantas" e de "mitaines" ${ }^{40}$ de lã.

Quanto ao refeitório, as fontes são ainda mais omissas, não possibilitando ir além da inventariação de algumas peças da louça utilizada como serviço da mesa (chávenas, copos, canecas, etc.) ou da informação sobre alguns consumos alimentares. Os documentos mencionam sobretudo o vinho "para o jantar"41, presente nas despesas de 9 alunas (22\%), arráteis de bolachas e ainda o leite, sobretudo de "jumenta". O consumo desta qualidade de leite, conhecido pelo seu valor energético, pode explicar-se por razões de saúde, uma vez que as mesmas crianças que o tomavam "pela manhã" eram também obrigadas a ingerir o famigerado "óleo de figado de bacalhau". A carne também entraria com uma certa regularidade na alimentação das educandas. A frequência com que as "bulas" ${ }^{2}$ são referidas nas despesas individuais, embora com maior insistência nos meses de Outubro a Dezembro, faz supor uma certa indulgência relativamente às interdições religiosas que pesavam sobre o consumo da carne.

Mas há outras matérias sobre as quais as despesas eventuais lançam pistas... É o caso, entre outras, dos cuidados de higiene ou do vestuário usado. Nas descrições conhecidas deste Colégio nenhuma alude à existência de instalações sanitárias. Presume-se, no entanto, que existiriam, junto aos dormitórios, salas próprias onde cada jovem dispunha de um "lavatório", um "espelho", uma "bacia de mãos" e uma "saboeira" devidamente identificados. Cada uma tinha ainda uma "escova dos dentes", uma "escova das unhas", vários pentes ("finos", "de alisar", etc.), sabão ou sabonetes. A avaliar pelos apetrechos inventariados, a higiene diária reduzia-se a lavagens parciais, pelo menos do rosto, mãos e boca.

As religiosas Ursulinas parecem seguir, nesta matéria, os preceitos higiénicos sugeridos por Mr. Prevost na sua obra Elementos de Civilidade e da Decência [...], manual de civilidade adoptado no Colégio, que recomendava que se desse particular atenção à limpeza da cabeça, dos olhos, dos dentes e das unhas, bem 
como dos pés, "principalmente em tempo de verão"43. Os banhos eram, por certo, pouco frequentes e talvez mesmo só tomados por prescrição médica. Esta conclusão é sugerida pelo facto de apenas três alunas os incluírem nas suas despesas eventuais, tomando-os com uma frequência pouco usual para o tempo: média de um banho cada oito ou dez dias ${ }^{44}$. Embora esta higiene nos pareça, aos olhos de hoje, bastante deficiente ${ }^{45}$, não o era segundo os padrões da época, que recomendavam que "se lavasse o que estava exposto ao ar", nem de acordo com a própria moral religiosa que aconselhava a evitar os "excessos de asseio", suspeitos de "luxúria e de voluptuosidade" (Csergo, 1988: 32).

Maior atenção mereciam os cabelos e o vestuário. A preocupação com a aparência exterior que, de acordo com o manual de civilidade adoptado, se deveria pautar pelos critérios da modéstia e da simplicidade, impunha a observância de certas regras quanto aos aspectos corporais visíveis ao olhar dos outros "porque aquelas pessoas, que são negligentes nesse ponto, pecam sempre contra a decência, e passam por incivis" (Prevost, 1787: 28). Os cabelos deveriam estar sempre bem penteados e presos de forma a não darem uma imagem de desleixo; os vestidos sempre "limpos, e asseados" (Prevost, 1787: 24). As despesas reflectem estas exigências, recenseando, no que respeita ao primeiro aspecto, uma profusão de atavios destinados a prender ou fixar o cabelo: "travessas", "ganchos", "bandinhas", "fitas de veludo", "redes de crochet" e ainda "banhas e pomadas para o cabelo". Quanto ao segundo aspecto, a lavagem e a engomagem da roupa constitui uma rubrica regular no cômputo geral das despesas, correspondendo a um gasto médio de 2806 réis por trimestre.

A forma de vestir das educandas obedece a considerações profundamente moralistas, impondo-se-lhes a sobriedade e a "decência", ou sendo pretexto para reflexões sobre o mérito do trabalho. A exemplo de outros colégios católicos, o uniforme era austero, senão mesmo sombrio, em tons de roxo e negro ${ }^{46}$, cores evocativas da simbologia religiosa da Ordem: as Chagas de Cristo. Em rigor, o uniforme só era usado em ocasiões especiais (para "assistirem no coro" às festividades religiosas, para receberem as visitas na grade, etc), vestindo as educandas, no dia-a-dia, "como qualquer menina na casa de sua familia mas sem luxo" (Abreu, 1857: 203). Esta disposição, pouco usual nos pensionatos oitocentistas que, de uma forma geral, impunham o uso regular do uniforme, tinha como fundamento razões de ordem económica e social: "acostumarem-se a cuidar do concerto deles [dos vestidos], e a apresentar-se no mundo"47.

Por volta de 1880 , poucas seriam as educandas a remendar a sua própria roupa, pagando para que outros o fizessem, como o demonstra o Quadro VIII. Esta ocupação era vantajosa para a economia doméstica, útil como iniciação à aprendizagem do trabalho e uma garantia face aos revezes da fortuna. A costura era uma das poucas actividades a que se poderia dedicar uma mulher honesta, em situação económica difícil, sem ser condenada pela opinião pública. 


\section{Quadro VIII \\ DISCRIMINAÇÃO DAS DESPESAS COM O VESTUÁRIO (EM RÉIS)}

\begin{tabular}{|lrr|}
\hline & Quantia & \multicolumn{1}{c|}{$\%$} \\
Aquisição e confecção de vestuário & 636150 & 52,3 \\
Manutenção e reparação do vestuário & 83385 & 6,9 \\
Calçado e sua manutenção & 365185 & 30,0 \\
Lavagem e engomagem de roupa & 131890 & 10,8 \\
Total & 1216610 & 100 \\
\hline
\end{tabular}

Fonte: Boletins trimensais das despesas eventuais das Educandas do Real Colégio Ursulino (1874 a 1880).

Além disso, para uma mulher cristã, "coser e remendar" era uma extensão das suas actividades caritativas e sinónimo da sua dedicação aos mais desfavorecidos. Para as jovens educandas, tratar da sua própria roupa era, pois, mais importante pela mensagem veiculada do que pelos resultados práticos alcançados.

$\mathrm{O}$ vestuário quotidiano era discreto, mas farto. A profusão de peças de roupa inventariada era de tal ordem que exigiria um estudo à parte. Em rigor, trata-se da despesa que mais sobrecarregava os orçamentos individuais, sendo um terço do seu montante $(36,1 \%)$ absorvido com os custos do uniforme e do vestido da

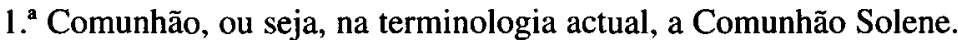

Cerimónia da maior solenidade no Colégio, a $1 .{ }^{a}$ Comunhão revestia para as jovens grande significado espiritual. Feita tradicionalmente aos 12 anos, este importante rito de passagem marcava simultaneamente a sua entrada na vida cristã e o fim da infância ${ }^{48}$. Com a $1 .^{a}$ Comunhão, terminava uma etapa da sua educação moral e religiosa, fechava-se um ciclo de vida. A menina dava lugar à adolescente.

A cerimónia estava à altura das circunstâncias: "pomposa", "tocante", "comovente" ${ }^{\text {. A }}$. As descrições exaltam-na e evocam um ambiente de grande emoção e espiritualidade. Apenas um exemplo: "Quem se aproximasse do Colégio das Ursulinas desta cidade no dia 7 deste mês [Julho], e, atraído pelos sons melodiosos e suaves do órgão, entrasse na devota egreja do Colégio, ficaria absorto e enlevado com o que ali se passava. Hinos religiosos, harmoniosos concertos, muitas flores, muitas galas festivas, tudo transpirando alegria [...] Entre uma selecta reunião de senhoras e cavalheiros, em cujo rosto se divisava o júbilo e a alegria, realçava o vulto proeminente do ilustre antistide conimbricense [...], celebrando o sacrifício incruento dos nossos altares, para ministrar a Sagrada Eucaristia a 24 meninas que pela primeira vez esperavam o momento feliz de se unir com o seu Deus e de o encerrar no seu coração. A alvura deslumbrante das suas vestes e 
as coroas que lhes ornavam a fronte simbolizavam a pureza daquelas creaturas felicíssimas" 50 .

Realizava-se geralmente em Julho a cerimónia tão esperada. Nesse dia, a jovem educanda vestia-se a rigor, completamente de branco, como uma pequena noiva: vestido, véu, coroa, sapatos. Nas mãos uma vela. Os documentos deixam também transparecer a mundanidade desta celebração, sugerida pela preparação cuidada do vestuário e pelo seu preço relativamente elevado: cerca de 10000 réis (Quadro IX).

Porém, era um dia para recordar. Afinal, não disputava ao casamento o título de "o mais belo dia da vida" (Fugier, 1990: 251)?

\section{Quadro IX \\ PREÇO MÉDIO DO VESTIDO DA 1 a $^{\mathrm{a}}$ COMUNHÃO (EM RÉIS)}

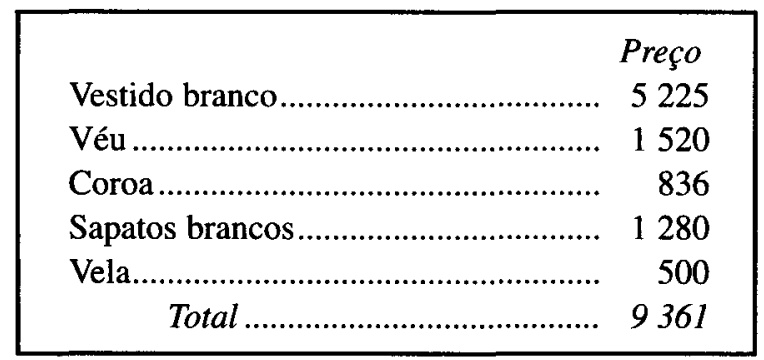

Fonte: Boletins trimensais das despesas eventuais das Educandas do Real Colégio Ursulino (1874 a 1880).

\section{5. "PARA SER VERDADEIRAMENTE CHRISTÃ, A MULHER TEM DE SER ILLUSTRADA" (MGR. DUPANLOUP): ALGUNS ASPECTOS DA INS- TRUÇÃO FEMININA}

A maior parte do dia das educandas era ocupado com os estudos e o ensino das "prendas". Na ausência de informações precisas sobre o horário praticado torna-se difícil avaliar com rigor a carga lectiva. É provável, no entanto, que esta não se distanciasse muito da que vigorava no Real Colégio Ursulino das Chagas, de Viana do Castelo, que reservava 6 horas e 30 minutos, por dia, à instrução, e cerca de 2 horas à formação religiosa e aos exercícios espirituais (Rocha, 1996: 145). Uma carga horária exigente semelhante à actualmente prevista nos programas escolares, agravada, pelo menos em princípio, pela ausência de interrupções por motivo de férias ou de saídas temporárias. $\mathrm{O}$ ano escolar começava, oficialmente, a 1 de Outubro, iniciando-se as aulas, o mais tardar, após a cerimónia de abertura solene do Colégio, em meados do mês ${ }^{51}$, e terminava no fim de Agosto com os exames. Uma periodização que se traduzia, em termos de carga lectiva, em cerca 
de 10-11 meses úteis. A relativa brevidade das estadias era, assim, compensada pela sua intensividade, rentabilizando-se ao máximo o tempo de internato.

A educação ministrada no Real Colégio Ursulino das Chagas assentava numa sólida formação religiosa que incluía o ensino da doutrina cristã, em particular do catecismo, e a explicação sucinta do Evangelho. Ao catecismo era reservada meia hora todas as quintas-feiras e domingos de manhã, enquanto à interpretação dos textos sagrados ou, em alternativa, a breves prelecções sobre "a excelência e prática das virtudes cristãs, sobre o respeito e amor devido aos superiores, sobre a caridade para com todos, etc." (Lemos, 1862: 52), era dedicada uma parte da tarde dos dias santificados. Completavam a formação religiosa, a prática de exercícios piedosos e a assistência diária à missa, bem como a preparação para a recepção dos sacramentos, entre os quais a 1. ' Comunhão. A religião, como seria de esperar num colégio católico, impregnava tudo, estando incorporada no universo quotidiano das educandas. As orações e as leituras edificantes ritmavam o dia-a-dia, sendo quase impossível separá-las do resto das actividades: rezava-se de manhã, no Oratório e na missa; nas aulas, no início e no fim; ao anoitecer, nos educandados, depois do toque das Avé-Marias; ao deitar, no dormitório. Contudo, apesar do lugar central que a religião ocupa na estrutura educativa, é difícil avaliar a sua influência no ensino ou o seu impacto junto das educandas. $O$ mesmo é válido para as regras e princípios de civilidade, vulgo educação moral e cívica, em cuja aprendizagem os Regulamentos punham tanto empenho.

O plano de estudos proposto pelo Colégio associava conhecimentos práticos e intelectuais, designados por ensino artístico e literário, cujo conteúdo temático estava subordinado ao objectivo concreto de preparar as jovens para as funções de esposa, de mãe e de dona de casa. As ciências exactas e naturais estavam ausentes, inclusive a aritmética, o que se adequava à vocação humanística dos colégios católicos e ao tipo de instrução considerado mais apto para o sexo feminino, não se pretendendo desenvolver a reflexão e o espírito crítico.

Pelo ensino literário a aluna aprendia a ler, a escrever e a contar; fazia ainda o estudo da gramática (portuguesa, francesa, italiana e inglesa), do desenho linear com aplicação aos lavores e aos bordados, da geografia (em especial corografia portuguesa), de história sagrada e profana e elementos escolhidos de mitologia. Princípios, regras e usos gerais de economia doméstica (governo de uma casa) e noções básicas de higiene completavam este ramo do ensino. $\mathrm{O}$ ensino artístico, por sua vez, distribuía-se por duas secções, sendo a primeira consagrada à aprendizagem de pontos de malha (fazer meia, renda, crochet, espigar, fazer luvas e outros trabalhos de lã), de costura (cozer, talhar, marcar, etc.) e de "bordadura" (bordar a branco, a cordonnet, a matiz, a cabelo, a seda, a froco, a escomilha, a ouro e prata, a missanga, a pó de lã, petit point, em vidro, em madeira, etc.). A segunda secção incluía o ensino da música (cantar e tocar piano) e da florística (fazer flores) $^{52}$. 
Trata-se de uma formação de conteúdo eminentemente doméstico que, sem negligenciar a instrução intelectual, beneficiava os lavores e os trabalhos manuais, elementos essenciais da educação feminina no século XIX. As despesas eventuais reflectem a importância do "ensino artístico" na programação geral do curso: $49 \%$ das despesas escolares são absorvidas com o pagamento dos materiais e dos objectos destinados aos "trabalhos de mãos", $27 \%$ com o equipamento necessário ao ensino da música e apenas $17 \%$ com os livros e respectivas encadernações (Gráfico I). Os gastos com o material escolar (papel, penas, tinta, canetas, cadernos, folhetos) e com a "luz para estudar" (estearina, azeite, candeeiros, etc.) completavam esta despesa.

\section{Gráfico I}

DESPESAS ESCOLARES: REPARTIÇÃO POR RUBRICAS (VALORES PERCENTUAIS)

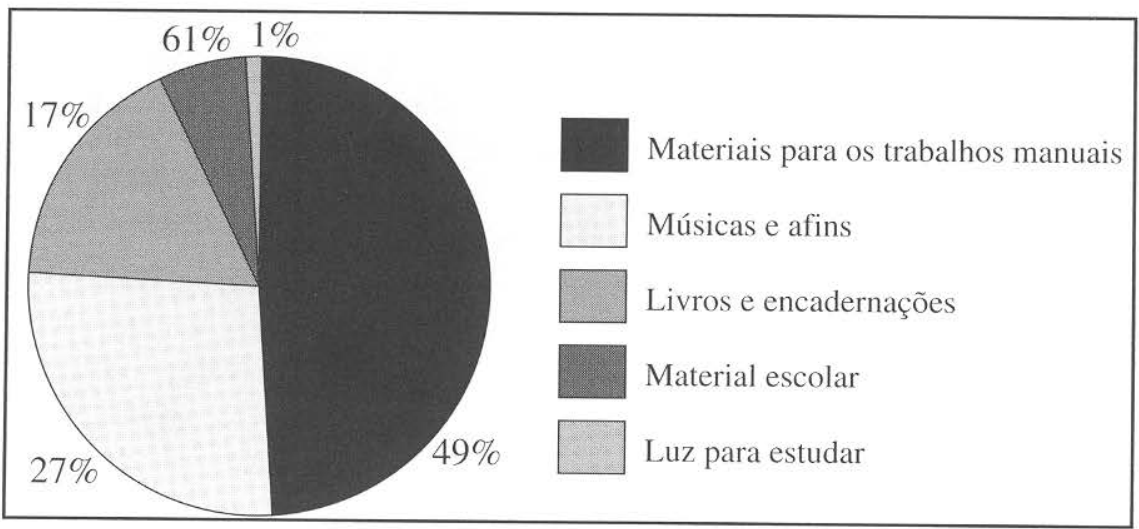

A lista dos artigos compulsados para os lavores é heterogénea, recenseando-se objectos indispensáveis à sua confecção (dedais, agulhas, botões, linhas, tesouras, furadores, bastidores, etc.), bem como os respectivos materiais, desde os mais simples como as talagarças, as lãs, as linhas para o crochet ou as meadas de fio de coco aos mais sofisticados e de preço elevado como as sedas, o moiré, as pratas e os "ouros de Itália" para bordar. Os documentos aludem igualmente a alguns dos trabalhos executados pelas alunas: bordados, almofadas, colchas, carteiras, quadros, tapetes, bancos de piano, pregadeiras, charuteiras, "porte-montres". Enfim, verdadeiras "prendas" que se destinavam a cultivar na jovem o gosto pelo trabalho e a desenvolver o seu sentido estético, sem qualquer finalidade utilitária, nem se pretendendo garantir uma especialização profissional. Os trabalhos realizados eram expostos anualmente no Colégio, por ocasião da cerimónia da entrega dos 
prémios, chegando alguns, pela qualidade e primor de execução, a ser apresentados nas exposições distritais ${ }^{53}$.

O estudo de um instrumento musical bem como do canto, não sendo obrigatório, fazia também parte da educação de uma jovem de sociedade. Não se tratava de formar virtuosas do belo canto ou executantes perfeitas mas tão-só aprender a tocar "sem ofender as teclas nem os ouvidos" (Levy, 1984: 33). Como instrumentos musicais os documentos mencionam apenas o piano, evocado geralmente pelos encargos de manutenção (afinação, consertos, transporte). Quanto às músicas discriminam-se as de "cantar" e as de "tocar", não se avançando na sua especificação. $O$ estudo do desenho, tal como as restantes disciplinas artísticas, adequava-se à finalidade doméstica do ensino, estando orientado para a aplicação ao corte.

No que concerne à formação intelectual propriamente dita, a aprendizagem das línguas estrangeiras, em particular da língua francesa, ocupava um lugar destacado. Em rigor, afigura-se mesmo como a única disciplina que implicava um trabalho escolar intensivo, inventariando-se um lote significativo de materiais indispensáveis ao seu estudo (luz, mitaines, etc.) e sem paralelo com qualquer outra área do saber. Já o estudo da língua inglesa não é consensual, figurando uma única aluna com livros indispensáveis a esta disciplina.

Os manuais adoptados pelo Colégio para o ensino e exames das meninas, por volta de 1870, não constam da lista de livros autorizados pelo Conselho Superior da Instrução Pública para a instrução primária ${ }^{54}$. A sua selecção, da responsabilidade da direcção do Colégio, obedece a critérios pouco neutrais, incidindo quase exclusivamente sobre obras redigidas por eclesiásticos. Esta orientação ideológica traduz a vontade manifesta de educar as crianças segundo conviç̧ões religiosas, assegurando-se a prioridade da transmissão dos valores espirituais sobre os valores temporais. Para a leitura prescreviam-se os Principios de Civilidade ou Regras Gerais da Educação, do P. Carreira de Melo (1. ${ }^{a}$ classe), Lugares Selectos, do P. Cardoso, e Poesias selectas, de Henrique Midosi (2. classe) ${ }^{55}$; para as disciplinas de geografia e de história adoptavam-se as obras Epitome de Corografia Portuguesa, do P. Carreira de Melo, e o Resumo da História Moderna de Portugal, do P. Mota Veiga; para a disciplina de francês aconselhava-se a Nova gramática elementar da língua francesa, pelo P. José A. Vieira da $\mathrm{Cruz}^{56}$. Alguns destes manuais são mencionados nas despesas, embora com o título truncado, fazendo-se ainda referência, como obras de apoio ou materiais didácticos, a "atlas", a "livros e a gramáticas de português para as classes", a "livros para a semana santa" e a "tabuadas"57. A avaliar por estes equipamentos escolares, as salas de aula estavam relativamente bem apetrechadas, sem comparação com as do ensino público, bastante mais sumárias. Os gastos com os livros de estudo não eram, no entanto, relevantes no cômputo geral das despesas escolares, nem comuns a todas as alunas. Já o mesmo se não aplica aos "folhetos para escrever 
os temas", o que sugere a transcrição em cadernos das matérias expostas oralmente pelas professoras. Indícios que parecem apontar para um tipo de ensino que privilegiava o método catequético à prática da leitura e que apelava à capacidade de memorização mais do que à imaginação e à espontaneidade individuais.

A metodologia seguida, comum de uma forma geral a outras instituições de ensino feminino tanto nacionais como estrangeiras, baseava-se na emulação ${ }^{58}$, expressa na cerimónia oficial da distribuição dos prémios às educandas que anualmente se distinguiam pelo seu "comportamento, aplicação e aproveitamento". Sob a presidência do bispo de Coimbra e perante uma assembleia atenta e respeitosa, esta cerimónia revestia-se de uma grande solenidade ${ }^{59}$. A sua prática manter-se-á em colégios católicos já do nosso século constituindo, no dizer de Maria Manuel Vieira, "uma ocasião de socialização para a apresentação pública e de aprendizagem da arte de saber estar perante ou outros" (1993: 36). A competição entre as alunas era incentivada por meio de uma série de práticas (afixação de Tabelas das educandas, recompensas, etc.) que procuravam recriar nas classes uma hierarquização baseada no comportamento exemplar e no mérito, ou seja, de acordo com a terminologia colegial, na "aplicação" e na "diligência".

A impressão de austeridade que se colhe destes testemunhos dispersos não deixa de suscitar uma certa perplexidade senão mesmo cepticismo quanto ao seu cumprimento e eficácia. Na verdade, as religiosas Ursulinas procuravam atenuar o rigor dos Regulamentos e tornar o mais agradável possível a existência das suas jovens pensionistas. Proporcionavam-lhes magustos, permitiam a aquisição de "brincadeiras de entrudo", não recorriam aos castigos corporais. Manifestavam, enfim, uma grande humanidade e davam provas de uma verdadeira indulgência maternal.

Na última década do século XIX o programa curricular será ligeiramente alterado, passando a incluir noções de economia doméstica e da "arte de bem receber" em sociedade, começando o Colégio a organizar, todos os meses, soirées que constavam de música, canto, dança e recitação de poesia ${ }^{60}$. Procurava-se desta forma preparar as jovens para as funções de gestão doméstica e de representação social adequadas ao modelo normativo burguês finissecular. Esta abertura efectuou-se num período pouco favorável ao ensino congreganista, acusado de "superficialidade e de má orientação" ${ }^{\text {"61 }}$ e segundo um plano de estudos desfasado dos programas oficiais. No preciso momento em que o ensino secundário propunha à sua clientela feminina o reforço da componente científica ou programas de estudo semelhantes aos dos rapazes ${ }^{62}$, o Real Colégio Ursulino das Chagas apostava na manutenção do statu quo e investia no ensino das "ciências domésticas" e na educação mundana, com a agravante de os seus estudos não serem sancionados por diplomas oficiais e não terem qualquer validade no mundo do trabalho.

O esforço de secularização desta ordem, tal como se verificou em França (Ostenc, 1980: 142-145; Mayeur 1980c: 197-205), e que conduziu a uma melho- 
ria da qualidade do ensino, fruto das exigências administrativas em matéria de qualificação pedagógica do corpo docente e da correlativa harmonização com os programas escolares oficiais, não se registou em Coimbra. As religiosas Ursulinas mantêm-se fiéis à educação tradicional e nem a concorrência do ensino secundário feminino as levou a reconsiderar o seu plano de estudos. A implantação da república interrompeu bruscamente a sua actividade lectiva, obrigando as religiosas a abandonarem a cidade ${ }^{63}$. Desta forma se pôs termo a cerca de meio século de dedicação à causa da instrução feminina em Coimbra.

\section{CONCLUSÃO}

As religiosas Ursulinas tinham um projecto pedagógico específico, singular, dirigido ao sexo feminino e condicionado a objectivos utilitaristas. Para os membros desta congregação, com um longo passado dedicado à instrução feminina, a educação não era um simples instrumento de progresso material ou de acesso ao conhecimento mas constituía um meio de preparar as jovens para as futuras funções de esposa, de mãe e de dona de casa. Ofereciam às raparigas uma formação abrangente, de âmbito generalista, ligada às humanidades clássicas e a um conceito essencialmente literário de cultura, mas não negligenciavam os aspectos práticos de uma futura vida doméstica. Os programas, as disciplinas, os conteúdos temáticos, as formas de aprendizagem obedeciam não só a objectivos pragmáticos mas eram também instrumentos poderosos da formação do carácter e da sensibibilidade femininas. Neste contexto, a sua estratégia pedagógica contemplava a formulação de princípios que visavam a formação da personalidade na perspectiva de uma moral dominada por um grande rigor e austeridade. Procurava incutir-se nas jovens educandas hábitos de moderação, de modéstia, de contenção do corpo de modo a facilitar a interiorização de uma disciplina que deveria resultar de uma atitude interior e não fruto de pressões exteriores, tornando a criança mais receptiva a atitudes de obediência e de respeito.

Apoiantes incondicionais da política social da Igreja e partilhando dos seus pontos de vista sobre o papel das mulheres na sociedade, a qual as reconhecia como aliadas fiéis no processo de "reconquista de almas", as religiosas Ursulinas fazem sua a missão de preparar as jovens para a vida privada e familiar. A conversão da sociedade pela via feminina constitui, de facto, uma das grandes preocupações da Igreja no século XIX, face à laicização e ao avanço do anticlericalismo. $\mathrm{O}$ grande mérito das religiosas Ursulinas foi precisamente o de terem conseguido conciliar as preocupações da Igreja, no que respeita aos objectivos religiosos e morais, com as exigências de uma educação burguesa, oferecendo uma instrução cujo conteúdo temático ia ao encontro das necessidades das classes médias e superiores que pretendiam para as suas filhas uma formação adequada 
ao meio de origem, aos tempos que se viviam e aos papéis que as esperavam na sociedade. Enquanto o modelo "doméstico" persistiu as religiosas tiveram êxito, clientela e prestígio, dando provas de uma grande capacidade de iniciativa e de abertura de espírito, sabendo adaptar os programas curriculares à progressiva alteração dos papéis femininos, chegando no fim do século a investir na preparação prática e mundana de uma jovem de sociedade.

Os horizontes culturais da instrução que ministravam mantinham-se, no entanto, mais próximos dos modelos setecentistas do que dos padrões pedagógicos do século XX. Se, por volta de 1850, quando se instalaram em Coimbra, o seu ensino clássico era louvado e encorajado mesmo por aqueles que não aceitavam passivamente a abertura de colégios religiosos, no fim do século XIX, o seu programa de estudos, ao persistir voltado para o passado, já não suscitava o mesmo consenso. Às críticas de "frivolidade" e de "superficialidade" que se abateram sobre os colégios católicos femininos, as Ursulinas de Coimbra responderam com o reforço da componente funcional e prática no plano curricular, em detrimento da intelectual, o que as interditou de poderem rivalizar, em termos de qualidade e de rigor científico, com o ensino secundário feminino que então dava os primeiros passos. Durante anos, a formação que proporcionavam fora considerada de qualidade "superior", com uma configuração entre o ensino primário superior e o ensino secundário. Sem dúvida que assim poderia ser qualificado, atendendo à diversidade temática do elenco das disciplinas leccionadas, sem paralelo com a instrução sumária que recebiam as raparigas nas escolas primárias oficiais. A partir do momento em que o Estado avança na escolarização das raparigas, tentandose atenuar o atraso registado no sector e investir na sua formação secundária, de carácter científico, a instrução tradicionalista ministrada no Colégio, de cunho eminentemente doméstico, afigurava-se desactualizada e incapaz de corresponder às exigências dos novos tempos.

Poder-se-á considerar o Real Colégio Ursulino das Chagas de Coimbra elitista? Sem dúvida. Pela origem social das suas educandas e pela educação que ministrava, a qual aliava à aquisição de conhecimentos e a uma sólida formação moral e religiosa, a aprendizagem das boas maneiras e das regras de civilidade. Nesta medida, o Colégio funcionou como um instrumento privilegiado de socialização, ensinando as crianças a comportar-se, a agir em todos os momentos da vida, preparando-as inclusive para a prática do altruismo, enfim, a agir de acordo com o estatuto social de uma mulher das classes elevadas.

Este ensino elitista e selectivo não pode fazer esquecer a outra vertente da actividade desta congregação: o ensino das crianças dos meios desfavorecidos, sobre o qual praticamente nada de sabe. Em qualquer das circunstâncias, seja proporcionando um ensino de qualidade às "meninas ricas", seja alfabetizando as "meninas pobres", as religiosas do Real Colégio Ursulino das Chagas, de Combra, contribuíram para dar visibilidade e dignidade ao ensino feminino no século XIX. Um 
ensino, porém, que não se abria à emancipação feminina nem propunha uma reavaliação do lugar da mulher na sociedade mas, antes pelo contrário, preparava as jovens para o conformismo, para os papéis tradicionais de mãe, esposa e dona de casa. Nesta medida, a formação oferecida pelas religiosas Ursulinas obriga-nos a repensar o papel da educação na reprodução das discriminações de carácter sexual e na transmissão de estereótipos, e a pôr em causa a imagem tradicional que identifica a instrução como um instrumento privilegiado de acesso à identidade colectiva e à consciencialização femininas.

\section{NOTAS}

1 O Observador, de 14 de Setembro de 1850.

2 Basílio Alberto de Sousa Pinto (1793-1881), fidalgo cavaleiro da Casa Real e Visconde de S. Jerónimo por título concedido por D. Luís, foi lente da Faculdade de Direito e reitor da Universidade de Coimbra, entre 1859 e 1863 . Foi autor de uma monografia sobre o Real Colégio Ursulino (Pinto, 1850). Para uma biografia mais circunstanciada deste docente universitário, veja-se Rodrigues (1992:125;167).

3 "Allocução proferida pelo Ex. ${ }^{\mathrm{mo}}$ e Rev. ${ }^{\text {mo }}$ Sr. Bispo Conde na distribuição dos premios no Collegio de Santa Joanna em Aveiro no dia 23 de Agosto de 1887", Instituições Christãs, $\mathrm{n}^{\circ}{ }^{\circ}$, $\mathrm{V}$ anno, 20 de Outubro de 1887, 2. ${ }^{\mathrm{a}}$ série, 228.

${ }^{4}$ Constituem excepções, neste quadro geral, o excelente estudo de Rocha (1996) e o interessante e esclarecedor artigo de Moura (1996/1997).

5 Este acto jurídico é igualmente transcrito na documentação notarial sob a designação de "escritura de obrigação de alimentos", "escritura de obrigação à prestação de alimentos" e "escritura de pensão temporária".

${ }^{6}$ O levantamento da maior parte das escrituras notariais foi efectuado, há alguns anos, pela Dra. Maria Manuel Proença Ferreira de Almeida. Foi preciosa a colaboração desta colega, a quem muito agradeço. Proximamente será dada à estampa um estudo conjunto sobre a origem social das alunas deste Colégio, desde a sua fundação, em 1748, até à sua extinção, em 1910.

7 O Colégio Ursulino impunha ainda como condição de ingresso, a idade mínima de 7 anos e a máxima de 18 anos, bem como a apresentação de uma licença, por escrito, do prelado da Diocese, da qual deveria constar a certidão de idade e a confirmação de não padecimento de doença contagiosa. Cfr. Abreu (1857: 202-203).

${ }^{8}$ Esta percentagem reporta-se a 32 educandas, as únicas que dispõem de escritura notarial. Sobre as restantes 9 educandas não tenho qualquer informação sobre a data da sua admissão no Colégio.

${ }^{9}$ Sobre este período da história do Real Colégio Ursulino das Chagas, veja-se Vaquinhas, 1996.

${ }^{10}$ Instituições Christãs, 1. ${ }^{a}$ série, 19 de Fevereiro de 1883, n. $^{\circ} 4,120$. 
11 No Real Colégio das Chagas, de Viana do Castelo, as educandas pagavam, na década de sessenta do século passado, $30 \$ 000$ réis semestralmente, quantitativo este que se deverá ter mantido até à extinção do Colégio, em 1884 (Rocha, 1996: 149).

12 No Recolhimento do Paço do Conde, em Coimbra, a mensalidade, por volta de 1875, era de $6 \$ 000$ réis. Os custos desta casa religiosa incluíam ainda as seguintes despesas: $20 \$ 000$ réis no acto da entrada e o pagamento anual de um alqueire de azeite e de $20 \$ 700$ réis para a lavadeira (A.U.C., Tab. Simão Maria de Almeida, Livro n. ${ }^{\circ}$ 20, fl. 85-86). No Colégio de Nossa Senhora da Conceição, na Covilhã, a mensalidade das alunas internas, em 1881 , era de $8 \$ 000$ réis (Refoios, 1901: 38).

13 No Colégio de $S$. Fiel, no Louriçal do Campo, a mensalidade dos alunos de "1. a classe" era de $8 \$ 000$ réis (Refoios, 1901: 16).

14 Anúncio de $O$ Tribuno Popular, n. $^{\circ} 2085$, de 26 de Janeiro de 1876.

15 Anúncio de $O$ Tribuno Popular, n..$^{\circ} 2085$, de 26 de Janeiro de 1876.

16 (Abreu, 1857: 204). Para um confronto com outras listagens dos objectos necessários aos alunos de colégios, veja-se, entre outros, $O$ Colégio da Bafureira-Parede (s.d.).

${ }^{17}$ A exigência de utilização de moeda metálica, ouro e prata, como modo de pagamento, excluindo qualquer forma de moeda papel, é uma prática bastante generalizada no sistema do crédito privado conimbricense. Esta exigência traduz o receio da não convertibilidade da moeda face a eventuais cursos forçados decretados pelo governo (Fonseca, 1978: 202-204 e Vaquinhas, 1980a: 83).

${ }^{18}$ Entre os eclesiásticos figuram como fiadores, para além do bispo de Coimbra, o Reverendo José Ferreira Fresco, cónego capitular da Sé de Coimbra (3 escrituras), e o Reverendo Francisco Homem de Nave Valente, procurador do Seminário de Coimbra ( 1 escritura).

19 D. Manuel Correia de Bastos Pina é indicado como fiador em duas escrituras notariais lavradas, respectivamente, por Bernardo José da Costa Basto, pai de Maria da Soledade da Costa Basto, e Bartolomeu da Costa Macedo Geraldes Barba de Menezes, 2. ${ }^{\circ}$ Visconde de Trancoso, pai de Maria do Carmo Geraldes Barba (A.U.C. Tab. Manuel José de Sousa, Livro n. ${ }^{\circ}$ 60, fl. 134, e Livro n. ${ }^{\circ}$ 64, fl. 27-27v). Para uma biografia deste destacado membro da hierarquia religiosa veja-se, entre outros (Ramos, 1995).

20 Trata-se de alguns casos cujas escrituras notariais não foram detectadas e que se reportam às seguintes educandas: Esménia Albuquerque Moreira, Lucinda Cândida de Lemos, Ludovina da Conceição Guimarães, Maria da Conceição Mendes, Maria Joaquina Correia e irmã, Maria Luísa da Costa e Almeida, Maria Manuel de Carvalho e Maria Margarida Bacelar.

${ }^{21}$ É o caso de Maria Luísa da Costa e Almeida, de Lucinda Cândida de Lemos e de Maria Joaquina Correia e irmã. A primeira, filha mais velha de Luís da Costa e Almeida, lente de Matemática, e de D. Ermelinda de Castro Freire de Vasconcelos, era sobrinha de D. Eugénia Cândida da Costa e Almeida, superiora do Colégio nos anos 1850-1865, e da mestra professora D. Maria da Glória das Costa e Almeida (Vaquinhas, 1996 b: nota 64). Quanto a Lucinda Cândida de Lemos parece tratar-se de uma sobrinha-neta de D. Manuel de Lemos, bispo de Coimbra de 1858 a 1865, filha de Luís Alves de Sousa Lemos, médico em Castelo de Vide, e de D. Teresa Lemos (Breyner, 1930: 336-337). Maria Joaquina Correia e irmã eram provavelmente sobrinhas de D. Manuel Correia de Bastos Pina. Na edição de 20 de Junho de 1885, a revista Instituiçôes Christãs mencionava que, na cerimónia da 1. Comunhão realizada a 21 de Maio de 1885, na Capela do Real Colégio Ursulino, "o senhor bispo conde teve a satisfação de ver entre as meninas sua sobrinha D. Delfina Correia Pina", n. ${ }^{\circ}$ 12, III anno, 1. ${ }^{\text {a }}$ série, 398.

${ }^{22}$ As localidades de residência das educandas eram as seguintes: Albergaria (1), Antuzede (1), Aveiro (1), Carregal do Sal (1), Castelo de Vide (1), Celorico da Beira (2), Coimbra (6), Elvas (1), Estremoz (1), Figueira da Foz (1), Lisboa (2), Lordosa (1), Lousada (1), Meda (1), Oliveira de Azeméis (2), Porto (1), Sabugal (1), Santar (2), Tábua (3), Tentúgal (1), Trancoso (1) e Vila Mendo (2). 
23 Este autor referencia os seguintes colégios femininos: Colégio de Nossa Senhora da Guia, Colégio da Regeneração e Conservatório do Menino Deus da Tamanca (concelho de Braga); Colégio de Nossa Senhora da Conceição (concelho da Covilhã); Colégio de Nossa Senhora da Divina Providência (concelho de Lisboa) e Colégio de Jesus, Maria, José e Colégio das Meninas de Lamego, ambos no concelho de Lamego (Abranches, 1874: 64, 106, 212, 248 e 484).

24 Neste levantamento não figuram os colégios dirigidos pelas religiosas Ursulinas, tanto em Coimbra como em Viana do Castelo.

25 Trata-se de 5 meninas órfãs de mãe, 3 de pai e 5 de ambos os pais.

26 O recorde de permanência no colégio é, no entanto, alcançado por uma aluna, Adelaide Pires de Lima, que tendo sido inscrita em 1858 é ainda dada como interna em 1880 (A.U.C., Tab. Vítor Madaíl de Abreu, Livro n. 68 , fl. 1v-2v). Tratar-se-á de um erro de datação? Ou estar-se-á perante o caso de uma pensionista convertida ao noviciado? Seja como for, 22 anos de internato é uma estadia demasiado longa para um colégio, mas não para quem pretenda professar.

27 As estadias em certos Colégios das Ursulinas, nos séculos XVII e XVIII, variavam entre três meses a dois anos (Annaert, 1992: 172; Provost, 1989: 261).

28 Na segunda metade do século XIX, a duração média da permanência nos pensionatos da Legion d'Honneur era de 5,3 a 6,2 anos (Rogers, 1992: 122).

29 A exigência expressa nas escrituras notariais de o pagamento da mensalidade se efectuar "sem rembolso algum mesmo por qualquer ausência", pode ser interpretado como uma prevenção cautelar relativamente a interrupções da escolaridade.

30 Eram considerados feriados, para além dos dias santificados, as quintas-feiras "das semanas em que não houver algum outro feriado, ordinario ou extraordinario", bem como os dias de aniversários e de festas reais e nacionais (Lemos, 1862: 58).

31 A única informação de que disponho é relativa a Rita Augusta de Santiago Gouveia de Almeida que ingressou no Colégio com 11 anos de idade. Esta menina nasceu na freguesia de S. Bartolomeu, em Coimbra, no dia 8 de Abril de 1864, tendo sido inscrita no Colégio a 30 de Abril de 1875 (A.U.C., Paroquiais - Baptismos, Freguesia de S. Bartolomeu, 1860 a 1865 e Tab. Manuel José de Sousa, Livro n. ${ }^{\circ} 64$, fl. 7v-8). Esta informação foi-me gentilmente prestada pelo meu colega Rui de Ascensão Ferreira Cascão, a quem muito agradeço.

32 Este princípio será também aplicado às classes de alunas externas aquando da sua abertura em 1883.

33 "Primeira Communhão no Real Collegio Ursulino", Instituições Christãs, n. ' 2, X anno, 20 de Julho de $1892,2 .^{2}$ série, 57-59.

${ }^{34}$ Instituições Christãs, n. ${ }^{\circ} 7,5$ de Abril de $1883,1^{a}$ série, 207; n. ${ }^{\circ}$, 20 de Abril de 1884 , $1^{\text {a }}$ série, 265-266 e n. ${ }^{\circ} 8,20$ de Abril de 1885, 1. ${ }^{a}$ série, 272.

35 Em 1891, a revista Instituições Christãs (n. ${ }^{\circ}$, de 20 de Outubro de 1891, 252) dava conta da chegada a Coimbra de três religiosas Ursulinas, duas de nacionalidade francesa e uma inglesa, que vinham ensinar música, piano e línguas francesa, alemã e inglesa. No ano seguinte, em 1892, a 19 de Outubro, a Gazeta Nacional informava da deslocação a esta cidade de uma religiosa de origem francesa, especializada no ensino do desenho, em especial do desenho sobre estofo. Outros exemplos se poderiam aduzir.

36 Veja-se, entre outros, o artigo de Maria de Azevedo, "A educação da mulher (Cartas simples)", A mulher e a criança, Anno I, Junho, Julho e Setembro de 1909, n. ${ }^{\circ} 3,4$ e 6 . Sobre este assunto, veja-se também Grainha (1891: 299-309).

37 O horário deste Colégio não se deveria afastar muito do fixado para o Real Colégio das Chagas, de Viana do Castelo, reconstituído por Manuel Inácio Rocha. As crianças levantavamse às 6 horas da manhã e terminavam as suas actividades às $20 \mathrm{~h} 30 \mathrm{~m}$ com a "lição, exame (de consciência), ladainha e ponto da meditação para o dia seguinte" (Rocha, 1996: 145). Para um 
confronto com os horários praticados em outros colégios desta congregação veja-se, entre outros, Bertout, (1935:107).

38 Sobre a função da jardinagem nos planos de estudos femininos veja-se Lévy (1984: 50).

${ }^{39}$ Segundo o relato de Bulhão Pato, na rua da Calçada, por onde passou o cortejo real, encontravam-se sobre uma "especie de pedestal, duas crianças das Ursulinas, vestidas de branco, com cestos de flores nas mãos" (1894: 53).

40 Trata-se de luvas sem dedos. Aparecem com frequência nesta documentação, sendo quase sempre referenciadas por "mitaines para o estudo do francês".

${ }^{41} \mathrm{O}$ vinho entrava habitualmente nas refeições das crianças. Maria de Fátima C. G. E. Silva Caldeira detectou-o nos "menus" de algumas cantinas escolares, bem como em asilos da cidade de Lisboa, durante o período da I República (1. ${ }^{\circ}$ vol., 1993: 110, 141-142, 190-191).

42 Trata-se provavelmente da "Bula da Santa Cruzada". Sobre o assunto veja-se "Actos episcopais no governo da diocese de Coimbra", Instituições Christãs, n. ${ }^{\circ} 4$, VIII anno, 20 de Fevereiro 1890, 107 e Neto, 1996: 185-189.

43 (Prevost, 1787: 20-28). O exemplar desta obra, depositado na Biblioteca Geral da Universidade de Coimbra, tem manuscrita a indicação "Real Colégio Ursulino".

44 Esta média foi obtida dividindo o números de banhos pelo número de dias correspondente ao período temporal a que se reportam.

${ }^{45}$ A situação não era diferente em alguns colégios masculinos. No Colégio de S. Fiel, no Louriçal do Campo, "os alumnos não tomam banho, senão quando lhes são recommendados pelo medico; como medida hygienica nunca" (Refoios, 1901: 26).

${ }^{46} \mathrm{O}$ uniforme era de cor roxa, sendo a manta e o véu negros.

47 Deve-se a Fr. Alexandre Palhares, director espiritual do Colégio de Pereira nos finais do século XVIII, a institucionalização desta regra (Pinto, 1850: 30).

48 Sobre a noção e limites cronológicos da adolescência no século XIX veja-se, entre outros Thiercé, 1996: 75-90; Dubesset e Zancarini-Fournel, 1993: 22-23.

49 A pompa de que esta cerimónia se revestia é considerada por Anne Bertout uma "instituição Ursulina" (Bertout, 1935: 115).

50 "Primeira comunhão no Real Collegio Ursulino", Instituições Christãs, n. ${ }^{\circ} 2, \mathrm{X}$ anno, 20 de Julho 1892, p. 57. Esta cerimónia é regularmente descrita na imprensa local. A título exemplificativo cite-se apenas $O$ Conimbricense, de 2 de Julho de 1887.

51 Sobre a cerimónia de abertura solene do Colégio veja-se, entre outros, Gazeta Nacional, de 19 de Outubro de 1892.

52 Sobre os programas deste Colégio veja-se, entre outros, O Instituto, vol. III, pp. 145-146 e Abreu, 1857: 201-202.

${ }^{53} \mathrm{Na}$ Exposição Distrital de Coimbra, do ano de 1884, as religiosas Ursulinas expuseram vários quadros bordados, destacando-se um, em escomilha, que retratava $\mathrm{D}$. Pedro $\mathrm{V}$ e a vista do Castelo da Pena, em Sintra (Instituições Christãs, II anno, 5 de Fevereiro de 1884, 95).

54 Abreu, 1857: 207-310; "Relação dos livros approvados e adoptados pelo Conselho geral de instrucção publica, para poderem ser lidos nas escolas publicas de instrucção primaria e secundaria, na conformidade do decreto de 31 de Janeiro de 1860", Boletim Official de Instrucção Publica, n. ${ }^{\circ}$ 10, Outubro 1861, Lisboa, Imprensa Nacional, 334-337.

${ }^{5 s} \mathrm{O}$ título completo desta obra, a única a que tive acesso da lista indicada, é o seguinte: Poesias Selectas para leitura, recitação e analyse dos poetas portuguezes em conformidade com os programmas adoptados para o curso de portuguez, decima edição, Lisboa, Imprensa Nacional, 1875.

56 Estas informações foram-me amavelmente prestadas pela minha colega Maria Teresa Nobre Veloso, a quem muito agradeço. Para o ensino do desenho seguiam-se as indicações con- 
tidas na obra Le Dessin Linéaire des Demoiselles, de Lamotte (Pinto, s.d.: 17). O P. Joaquim Alves Pereira é indicado como autor da obra Elementos de Desenho Linear (para uso das educandas do Colegio das Ursulinas), Coimbra, 1853.

${ }^{57}$ Para uma descrição relativamente pormenorizada das salas de aulas veja-se Pinto, s.d.:16-19.

58 É o caso, no nosso país, entre outros, do Real Colégio das Chagas, de Viana do Castelo (Rocha, 1996: 144-145) e do Colégio de Santa Joana de Aveiro (Instituições Christãs, n. ${ }^{\circ}$, $\mathrm{V}$ anno, 20 de Outubro de 1887, 225-229 e n. ${ }^{\circ}$ 7, IX anno, 5 de Outubro de 1891, 193-212).

$59 \mathrm{Na}$ impossibilidade de citar todas as referências a esta cerimónia na imprensa, veja-se, a título exemplificativo, Instituições Christãs, n. ${ }^{\circ}$ 4, VI anno, 20 de Agosto de 1888, 122-124; n. ${ }^{\circ}$ 4, VII anno, 20 de Agosto de 1889, 126; n. ${ }^{\circ}$ 3, X anno, 5 de Agosto de 1892, 103-104, 119 -123 e $O$ Conimbricense de 30 de Agosto de 1887.

${ }^{60}$ Gazeta Nacional, de 15 de Novembro de 1893.

61 Sobre a questão congreganista em Portugal no final do século XIX veja-se, entre outros, Grainha, 1891: 224-240; 271-290; 299-309; Catroga, 1991: 329-331, 379-387 e Neto, 1996: 309-321.

62 Sobre a implantação do ensino secundário feminino veja-se, entre outros, Rocha, 1991. Para uma análise dos programas veja-se Regulamento dos Institutos auctorisados pela lei de 9 de Agosto de 1888 e destinados ao ensino secundario feminino approvados por Decreto de 6 de Março de 1890 (1890), Lisboa, Imprensa Nacional.

63 A notícia do encerramento do Colégio é dada nos seguintes termos pelo jornal A Defeza, de 18 de Outubro de 1910: "Até que enfim! Foi hoje fechado o coio das Ursulinas. De nada valeu o respeitavel hissope do sr. Bispo Conde. Paciência !...".

\section{FONTES (MANUSCRITAS)}

"Boletins trimensais das despesas eventuais das Educandas do Real Colégio Ursulino (1874 a 1880)", Manuscrito n. ${ }^{\circ}$ 1286, Biblioteca Geral da Universidade de Coimbra (B.G.U.C., em posteriores referências) (Cfr. Catálogo de Manuscritos. Códices n. ${ }^{\circ} 1081$ a 1311 (1935), Coimbra, Biblioteca da Universidade.

Livros notariais, Arquivo da Universidade de Coimbra (A.U.C., em posteriores referências).

Tabeliães: Manuel José de Sousa (Livros n. ${ }^{\circ} 60$ a 66; Vítor Madaíl de Abreu (Livro n. ${ }^{\circ} 68$ ); Severo Sabino dos Santos (Livro n. ${ }^{\circ} 12$ ).

\section{FONTES IMPRESSAS E OBRAS DE CONSULTA}

ABRANCHES, Aristides (1874), Almanach Burocratico geral, districtal e concelhio para 1875, Lisboa, Empreza Editora-Carvalho \& C..

ABREU, José Maria (1857), Almanak da Instrucção Publica em Portugal, Coimbra, Imprensa da Universidade.

ANNAERT, Philippe (1992), Les collèges au féminin. Les Ursulines: enseignement et vie consacrée aux XVII et XVIII siècles, Bruxelles, Vie Consacrée.

242 ARNOLD, Odile (1984), Le corps et l'âme. La vie des religieuses au XIX'e siècle, Paris, Seuil. 
AZEVEDO, Maria de (1909), "A educação da mulher (Cartas simples)", A mulher e a criança, Anno I, Junho, Julho e Setembro de 1909, n. ${ }^{\circ}$ 3, 4 e 6.

BERTOUT, Anne (1935), Les Ursulines de Paris sous l'Ancien Régime, Paris, Typographie Firmin-Didot.

BREYNER, Prof. Thomaz de Mello, $4 .^{\circ}$ Conde de Mafra (1930), Memorias 1869-1880, Lisboa, Parceria Antonio Maria Pereira.

BRICARD, Isabelle (1985), Saintes ou pouliches. L'éducation des jeunes filles au XIX" siècle, Paris, Albin Michel.

CALDEIRA, Maria de Fátima C. G. E. Silva (1993), De meninos se fazem homens. Assistência infantil e juvenil na cidade de Lisboa durante a $1 .{ }^{a}$ República, 2 vols., Lisboa (tese de mestrado, mimeog.).

CATROGA, Fernando (1991), O republicanismo em Portugal. Da formação ao 5 de Outubro de 1910, Coimbra, Faculdade de Letras da U. C.

Colégio da Bafureira $(O)$ - Parede (s.d.), Lisboa, Tenebris Casa portuguesa.

CSERGO, Julia (1988), Liberté, égalité, propreté. La morale de l'hygiène au XIX $X^{e}$ siècle, Paris, Albin Michel.

DUBESSET, Mathilde; ZANCARINI-FOURNEL, Michelle (1993), Parcours de femmes. Realités et représentations. Saint-Etienne 1880-1950, Lyon, Presses Universitaires de Lyon.

FAYET-SCRIBE, Sylvie (1990), Associations féminines et catholicisme. De la charité à l'action sociale $X I X^{e}-X X^{e}$ siècle, Paris, Les Éditions Ouvrières.

FONSECA, Fernando Taveira da (1978), "Crédito privado em Coimbra no ano de 1885 visto a partir dos actos notariais. Alguns aspectos", Boletim do Arquivo da Universidade de Coimbra, vol. III, Coimbra, 161-225.

FRAISSE, Geneviève (1976), "La petite fille, sa mère et son institutrice (Les femmes et l'école au XIX ${ }^{e}$ siècle)", Les temps modernes, Petites filles en éducation, $31^{\mathrm{e}}$ année, Mai, $\mathrm{n}^{\circ}{ }^{\circ} 358$, 1959-1988.

FUGIER, Anne Marie (1990), “Os ritos da vida privada burguesa”, História da vida privada, tomo IV - Da Revolução à Grande Guerra, sob a direcção de Philippe Ariès e Georges Duby, tradução portuguesa com revisão científica de Armando Luís de Carvalho Homem, Lisboa, Círculo de Leitores, 193-261.

GRAINHA, M. Borges (1891), Os jesuitas e as congregações religiosas em Portugal nos ultimos trinta annos, Porto, Typ. da Empreza Litteraria e Typographica.

LAGRÉE, Michel (1995), "L'histoire de l'enseignement primaire catholique. Le problème des sources", L'enseignement catholique en France aux XIX"et $X X^{\varphi}$ siècles, sous la direction de Gérard Cholvy et Nadine-Josette Chaline, Les Éditions du Cerf, Paris, 25-34.

LANGLOIS, Claude (1980), "Aux origines de l'enseignement secondaire catholique des jeunes filles. Jalons pour une enquête, 1896-1914", Education et images de la femme chrétienne en France au début du XX' siècle - À l'occasion du centenaire de la mort de Mgr. Dupanloup, sous la direction de Françoise Mayeur et Jacques Godille, Lyon, L’Hermès, 81-94.

LELIÈVRE, Françoise; LELIÈVRE, Claude (1991), Histoire de la scolarisation des filles, Paris, Nathan.

LEMOS, D. José Manuel de (1862), Provisão Pastoral e Directiva para as Ursulinas de Coimbra pelo Excellentissimo e Reverendissimo Senhor D. José Manuel de Lemos, Coimbra, Imprensa Litteraria.

LÉVY, Marie Françoise (1984), De méres en filles. L éducation des françaises (1850-1880), Paris, Calman-Levy.

MAYEUR, Françoise (1974a), "Les catholiques libéraux et l'éducation des femmes", Les catholiques libéraux au XIX" siècle, Actes du Colloque International d'Histoire Religieuse de 
Grenoble dès 30 Septembre - 3 Octobre 1971, Avant-propos de J. Gadille, Presses Universitaires de Grenoble, 1974, 421-440.

MAYEUR, Françoise (1979b), L'éducation des filles en France au XIX siècle, Paris, Hachette.

MAYEUR, Françoise (1980c), "Vers un enseignement secondaire catholique des jeunes filles au début du XX' $\mathrm{XX}^{\mathrm{e}}$ siècle", L'enseignement catholique en France aux XIX $X^{e}$ et $\mathrm{XX}^{e}$ siècles, sous la direction de Gérard Cholvy et Nadine-Josette Chaline, Les Éditions du Cerf, Paris, 197-205.

MIDOSI, Henrique (1875), Poesias Selectas para leitura, recitação e analyse dos poetas portuguezes em conformidade com os programmas adoptados para o curso de portuguez, decima edição, Lisboa, Imprensa Nacional.

MOURA, Maria Lúcia de Brito (1996/1997), “As Doroteias em Portugal (1896-1910): uma difícil implantação", separata de Lusitania Sacra, 2." série (8/9).

NETO, Vítor Manuel Parreira (1996), O Estado, a Igreja e a Sociedade em Portugal 1832-1911, Coimbra, Faculdade de Letras.

NEUVILLE, Josephina (1864), Memorias da minha vida. Recordações de minhas viagens, Lisboa, Typographia do Panorama, vol. 1."

OSTENC, Michel (1980), "L'enseignement catholique pour les jeunes filles en Ardèche au début du $\mathrm{XX}^{\mathrm{c}}$ siècle", Education et images de la femme chrétienne en France au début du $X X^{e}$ siècle - À l'occasion du centenaire de la mort de Mgr. Dupanloup, sous la direction de Françoise Mayeur et Jacques Godille, Lyon, L'Hermès, 131-148.

PATO, Bulhão (1894), Memorias. Homens politicos, tomo II, Lisboa, Typographia da Academia Real das Sciencias.

PINTO, Basílio Alberto de Sousa (s.d.), Descripção da visita que o Excellentissimo e Reverendissimo Senhor Arcebispo, Bispo Conde, D. Manoel Bento Rodrigues, fez ao R. Collegio Ursulino das Chagas, em S. José de Coimbra.

PINTO, Basílio Alberto de Sousa (1850), Memoria sobre a fundação e progressos do Real Collegio das Ursulinas de Pereira, Coimbra, Na Imprensa da Universidade.

PREVOST, Mr. (1787), Elementos da civilidade e da decencia que se practica entre a gente de bem, traduzidos na lingua portugueza por Jozé Vicente Rodrigues, natural e morador na Cidade do Porto, Lisboa, Na Offic. de Antonio Gomes, Com licença da Real Meza da Comissão Geral sobre o Exame, e Censura dos Livros.

PROVOST, Georges (1989),"Les Ursulines en Léon et Cournouaille aux XVII et XVIII ${ }^{\mathrm{e}}$ siècles", Annales de Bretagne et des pays de l'Ouest (Anjou, Maine, Touraine), tome 96, $\mathrm{n} .^{\circ} 3$, 247-268.

RAMOS, A. Jesus (1995), O bispo de Coimbra D. Manuel Correia de Bastos Pina, Coimbra, Gráfica de Coimbra, Lda..

REFOIOS, Dr. Joaquim Augusto de Sousa (1901), O Collegio de S. Fiel no Louriçal do Campo e o de Nossa Senhora da Conceição na Covilhã. Apontamentos sobre o Jesuitismo, Coimbra, F. França Amado-Editor.

Regulamento dos Institutos auctorisados pela lei de 9 de Agosto de 1888 e destinados ao ensino secundario feminino approvados por Decreto de 6 de Março de 1890 (1890), Lisboa, Imprensa Nacional.

ROCHA, Cristina (1991), "Contribuição do ensino secundário liceal feminino para um modelo de educação pública da mulher - 1888-1940", separata de Ciências da Educação em Portugal. Situação actual e perspectivas, Porto, Sociedade Portuguesa de Ciências da Educação.

ROCHA, Manuel Inácio (1996), O Real Colégio das Chagas. Instrução de meninas em Viana (1778-1884), Viana do Castelo, Governo Civil de Viana do Castelo.

244 gensis 1772-1937, vol. II, Coimbra, Universidade de Coimbra. 
ROGERS, Rebecca (1992), Les demoiselles de la Légion d'Honneur. Les maisons d'éducation de la Légion d'Honneur au XIX' siècle, Paris, Plon.

SONNET, Martine (1987), L'éducation des filles au temps des Lumières, Paris, Les Éditions du Cerf.

THIERCÉ, Agnès (1996), “De l'école au ménage". Le temps de l’adolescence féminine dans les milieux populaires (Troisième République)", Clio. Histoire, femmes et sociétés, n. ${ }^{\circ} 4$, Le temps des jeunes filles, Toulouse, P.U.M., 75-90.

VAQUINHAS, Irene Maria (1980a), "O crédito hipotecário em Coimbra no ano de 1866. Tentativa de integração no desenvolvimento capitalista do século XIX", Boletim do Arquivo da Universidade de Coimbra, vol. IV, Coimbra, 1980, 39-84.

VAQUINHAS, Irene Maria (1996 b), "O Real Colégio Ursulino das Chagas de Coimbra. Notas para a sua história”, Revista Portuguesa de História, tomo XXXI, Coimbra, volume $2 .^{\circ}$, p. 427-447.

VIEIRA, Maria Manuel (1993), "Letras, artes e boas maneiras: a educação feminina das classes dominantes", Análise Social, vol. XXVIII (120), (1%), 7-53. 
ANE

Origem social do Real Colégio das

\begin{tabular}{|c|c|c|c|c|c|c|}
\hline \multirow[t]{2}{*}{ Nome* } & \multirow[t]{2}{*}{$\mathbf{N}^{\circ}$} & \multicolumn{3}{|c|}{ Data da escritura } & \multirow[t]{2}{*}{ Nome do pai ou tutor } & \\
\hline & & Ano & Mês & Dia & & \\
\hline Ádelaide Sofía Peixoto (Martins de Sousa Vilas Boas) & $T$ & 1875 & 4 & 27 & Manuel Pinlo Peixoto de Souss Vilas Boas (vińvo) & s.i. \\
\hline Alexandrima Xavier da Cumha & 1 & 1872 & 10 & 17 & Maximianto Xavier da Cunha & alferes dc \\
\hline Amélia (Augusta Correia de) Laceeda & $T$ & 1879 & 11 & 4 & Mavia do Carmo Conreia Lacenda & a.i. \\
\hline Anta (Margarida) Sacadura (Bote) & 1 & 1874 & i1 & 12 & Josto Sacadura Bote Corte-Real & si. \\
\hline Antónia Luisa (Canais) de Sousa Seco & $T$ & 1874 & 4 & 7 & Fransecisco Henriques de Souse Seco & $\begin{array}{l}\text { Juiz; caval } \\
\text { reglo }\end{array}$ \\
\hline Beatriz (de Abrea Pessoa) Brito Caldas & $\mathrm{I}$ & 1875 & $I$ & 7 & Ellsio Freire de Abreu Pessona Caldas & atvorado. \\
\hline Esménia Albuquerque Moretira & 1 & & & & s.i. & \\
\hline Florinda Josefa Rodrigues & 1 & 1878 & 10 & 23 & Manuel Rodrigues & alles do \\
\hline Goorgina Adelaide Almeids Machado & 1 & 1869 & 10 & 7 & Joso Jose dos Santos Machado & si. \\
\hline (Maria) Herminia Clotilde de Albuquerque (Mesquita de Paiva) & 1 & 1870 & 10 & 26 & $\begin{array}{l}\text { Marin Amólifi de Albuquerque Mesquita de Paiva e } \\
\text { Castro }\end{array}$ & si. \\
\hline Júlia Adelaide (Pires de) Lima & 1 & 1858 & 10 & 20 & António de Sousa Pires de Lim & propriectir: \\
\hline Jullia (Henrige & $T$ & 1880 & $\overline{4}$ & IS & Alexande de Am & inopiedir: \\
\hline Laurn Clementina de Castro & $\overline{1}$ & 1874 & 5 & 19 & Dinis de Castro & proprietiri \\
\hline Lucieda Chatida de Lemos & 1 & & & & Luils Atves de Sousa Neves & módico \\
\hline Ludovina da Concelch Go Guimartics & I & & & & \begin{tabular}{|l} 
s.i. \\
\end{tabular} & si. \\
\hline Maria da Solodede da Costa Bastos & $i$ & 1869 & 7 & 8 & Bennardo Jose da Costa Baseos & propiteter \\
\hline Marla Auquista (de Oliveira) Mourto & $\mathrm{t}$ & 1874 & 11 & 4 & Dr. Anobnio Jouk de Olivelra Mour bo & drogendo \\
\hline Maria dis Conceichio Merdes & $\frac{1}{1}$ & & & & s.t. & s.t. \\
\hline $\begin{array}{l}\text { María da GKoria (Morley Coello) (do) Amaral e irmi (MP } \\
\text { Clotilde) }\end{array}$ & $\overline{2}$ & 1878 & 5 & 22 & Dr. Bernando Coellio do Amaral (viúvo) & juiz de dis \\
\hline Maria da Piedade (de Carvalibo) Mirrbean & $T$ & 1874 & 10 & 3 & Dr. Berrardo António da Sema Mirmbeat & lentet de me \\
\hline Maria do Carmo Giraldes (Barba) & 1 & 1875 & 12 & 8 & $\begin{array}{l}\text { Bartolomeu da Costs Macedo Geraldes Barbe de } \\
\text { Menezes }\end{array}$ & $\begin{array}{l}\text { moso id } \\
\text { Trancoso) }\end{array}$ \\
\hline Maria dos Prazeres (Mencses de Ataide) & 1 & 1880 & 4 & 15 & Alexandre de Amaral Abrea Meneses & proprietin in \\
\hline Maria Eliss Fateira (de Abreu) & 1 & 1870 & 10 & 1 & Vicente Perreira de Abreu (vilivo) & proprietiri \\
\hline Maria Enilli Albuquerque & 1 & 1875 & 10 & 10 & António Cabr & proprietir \\
\hline Maria Emilia Pinto & 1 & 1876 & II & 14 & Alberto Eduardo de Souss & esentiviod \\
\hline Marda Esménia Guimaries & 1 & 1872 & 5 & 28 & Bento José da Siviva Gumarács (vióvo) & propitetin \\
\hline Marla Herminia (de Paiva Albuquerque) Mortira & 1 & 1878 & 5 & 4 & José Joaguim Henriques Moreira & coroned de \\
\hline Maria Josquina Correia e irma & 2 & & & & s.i. & \\
\hline Maria losé Magainses e irmb & 3 & 1872 & 3 & $\overline{30}$ & Apostinho Borges de Figuetrodo e Castro & bechuret $\mathrm{s}$ \\
\hline Maria Lúsa da Costa e Almeida & I & & & & Lús da Costa e Almeida & lente de $\mathrm{N}$ \\
\hline Maria Lúres (Pereira) Pimented & 1 & 1873 & 6 & 27 & Maria dos Prazeres Perein Pimentel & S.i. \\
\hline Maria Manuel de Carvaliho & 1 & & & & s.i. & s.i. \\
\hline Maria Margarida Bacelar & 1 & & & & s.1. & si. \\
\hline Marin Olmpinia (Peretra) Gomes & $\frac{i}{1}$ & 1874 & 5 & 28 & Manuel Gomes de S. Josk & \begin{tabular}{|l|l|} 
s.i. \\
.
\end{tabular} \\
\hline Rita Augusta (de) Samtiagso (Gouveia de Almelda) & $\frac{1}{1}$ & 1875 & 4 & 30 & Jamuário Amóntio de Almeida & ai. \\
\hline Saro Amulia Navaroo e irmi (Laura Branca) & 2 & 1876 & 10 & 18 & António Augusto de Matos Nivarro & propit \\
\hline
\end{tabular}

Fontes: Boletins trimestrais das despesas eventuais das Educandas do Real Colégio Ursulino (1874-1880) e Escrituras notariais. 


\section{Chagas de Coimbra (1869-1880)}

\begin{tabular}{|c|c|c|c|c|}
\hline Profíssino & Morada & Fiador & Profissta & Morada \\
\hline & Lousenda & Fruccisco Maria de Sousa Nazaré & negociante e proprietario & Colmbra \\
\hline \multirow[t]{3}{*}{ oxtrcito } & Trencose & Dr. Jose Josquim Fernandes Vaz & lente de Direlito & Coimbra \\
\hline & Meda & Dr. José Jasquim Femandes Vaz & lente de Diretio & Coimbre \\
\hline & Coimbre & Dr. Júlio de Sacadure Bote & lente do Medicina & Coimbra \\
\hline da ord de N Sr d Concelffio, deleg. procurador & Antuzede & Manuel Abilio Simbes de Carvalho & becharel em filosofia & Coimbra \\
\hline \multirow[t]{2}{*}{ Idministrador do conceliho } & Figueira do Foz & Dr. Francisco Antónto Dinic & profeseor do licen Nacional & Coimbra \\
\hline & s.i. & s.i. & s.i. & s.i. \\
\hline \multirow[t]{3}{*}{ scicrito } & Elvas & Dr. Raimuando da SilvaMota & lente de Medicina & Coimbra \\
\hline & Aveiro & Dr. Jasquim Cardoso de Anújo & lente de Teologin & Coimban \\
\hline & Lordosa & Indcio Raimundo Alves Sobral & s.i. & s.i. \\
\hline is & Coimbra & $\begin{array}{l}\text { Dr. Manull Augusto de Souse Pires \&e } \\
\text { Lima }\end{array}$ & lente de Teologin & Coimbra \\
\hline io & Vila Mendo & Dr. Bemardo do Albuguerque Amiand & lente de Medicing & Coimbn \\
\hline \multirow[t]{3}{*}{ iv } & Liston & Joso Henriques de Monis Calado & bacharel em Medicina e Matematica & Coimbra \\
\hline & Castelo de Vide & s.i. & s.i. & s.1. \\
\hline & s.i. & s.i. & s.i. & s.i. \\
\hline \multirow[t]{3}{*}{ i e dono de uns fabrieg de lanificios } & Ol. de Azemeis & Manuel Correia de Bastos Phra & viganio geral do bispado & Coimbra \\
\hline & Porto & Joaquim Francisco da Silva & s.l. & s.i. \\
\hline & 8.1. & s.i. & s.i. & s.l. \\
\hline ito (aposentado) & Samtar & António Goncalves da Silva e Cunha & lente de Medicina & Coimbra \\
\hline wicing & Coimbra & José Ferreina Fresco & Conego capitular da Sé & Coimbra \\
\hline $\mathrm{l}_{30}$, senhor de virios vinvulos ( $2^{\circ}$ visconde de & Lisboan & Mmuel Correia de Bastos Pina & bispo de Coimbra & Coimber \\
\hline 10 & Vila Mendo & Dr. Bemardo Albuquerque Amaral & lente de Medicina & Coimbra \\
\hline is & Ssobugl & rever, Francisco Homem de Nave Valente & $\begin{array}{l}\text { procurador do Semináro de } \\
\text { Coimbre }\end{array}$ & Coimbra \\
\hline is & Carregal Sal & Joute Agostinho Ribeiro Guimarties & proprietírio c becharel & Colmbre \\
\hline a reperticio da fazenda & Abegaria & António Josquim de Vasooncelos & delegado do tesouro & Coimbra \\
\hline (-) & Ol. de Azeméis & Jode Ferretina Freaco & conego capitular da Se de Coimbra & Coimbra \\
\hline \multirow[t]{2}{*}{ Exvalaria } & Estremoz & Dr. Goncto de Almeide Garret & lenie de Matemitica & Coimbra \\
\hline & s.t. & si. & S.t. & 8.1. \\
\hline n Direito & Thun & Pedro Aurusto Monteiro Castelo-Branco & lente de Direito & Colmbra \\
\hline \multirow[t]{6}{*}{ Intemśtica } & Coimbra & A.t. & s.1. & s.i. \\
\hline & Coimbar & Jose Fenting Fresco & conego capituler da St & Coimiora \\
\hline & s.i. & B.i. & s.i. & s.i. \\
\hline & 8.i. & s.1. & 8.i. & s.i. \\
\hline & Tentigal & Jollo Francisco da Silva & comerciante e propdetirio & Coimbra \\
\hline & Coimbin & Antonio Rodrigues Ptinto & negociante e proprietirio & Coimbra \\
\hline io e comerciante & Celorico Beirs & José Antonio da Costa Brags Júnior & comenciante & Coimbra \\
\hline
\end{tabular}

* - Os nomes e apelidos que se encontram entre parênteses foram detectados através das escrituras notariais ou das obras abaixo mencionadas. A sigla s.i. corresponde a "sem identificação".

Albano da Silveira (1866), Resenha das famílias titulares e grandes de Portugal, 2 tomos, Lisboa, Empreza Editora de Francisco Arthur da Silva.

Aristides Abranches (1874), Almanach Burocratico geral, districtal e concelhio para 1875, Lisboa, Empresa Editora - Carvalho e Ca.

Innocencio Francisco da Silva, Diccionario Bibliographico Portuguez. Estudos, tomo 2. , 2." ed., Lisboa, na imprensa Nacional, 389-390.

Memoria Professorum Universitatis Conimbrigensis 1772-1937 (1992), vol. II, direcção de Manuel Augusto Rodrigues, Coimbra, arquivo da Universidade de Coimbra.

Memorias do Prof. Thomaz de Mello Breyner, $4 .^{\circ}$ Conde de Mafra, 1869-1880 (1930), Lisboa, Parceria Antonio Pereira. 